\title{
Public-Private Partnerships In Spain: Lessons And Opportunities
}

Gayle Allard, (Email: gayle.allard@ie.edu), Instituto de Empresa, Spain

Amanda Trabant, Instituto de Empresa, Spain

\begin{abstract}
Public-Private Partnerships (PPP), a "marriage" between public- and private-sector activity, have been employed for almost two decades as a "third way" to optimize the use of public funds and boost the quality of services traditionally provided by the public sector. Their use has spread from the United Kingdom to Europe and beyond, and has expanded from the transport sector to innovative projects in health, education and others. In Spain, successive governments have seized on PPPs as a solution to budget constraints at a time of dwindling EU aid and stricter fiscal targets. As a result, the use of PPPs at all levels of government has exploded since 2003 and most recently culminated in a major infrastructure plan which relies on the private sector for $40 \%$ of its total investment. Undoubtedly, this trend will bring benefits to the Spanish population in terms of more abundant, lower-cost and higher-quality services. However, there are risks implicit in the way PPP is unfolding in Spain that could limit and even undo these benefits unless steps are taken to coordinate, monitor and follow up public-private projects and to communicate their virtues to the public. Spain presents an interesting paradox in the history of PPP. While it is one of Europe's oldest, most active and most enthusiastic users of PPP, it is at the same time one of the countries that has demonstrated least interest at an official level in informing, monitoring, regulating and following up projects to ensure that their deepest benefits are being achieved. Relying on PPP only for private financing entails a risk that the benefits of PPP will not be realized and public services will actually become more expensive and less satisfactory over the medium and long term. The Spanish government is advised to take steps similar to those taken in the United Kingdom, to ensure that PPP is managed correctly and hence becomes an asset and not a liability to Spanish citizens.
\end{abstract}

\section{BACKGROUND}

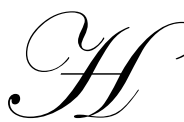

ow can public services best be provided to a nation's citizens? The question is an old one that has become particularly pressing as governments have expanded and moved into new areas of activity. Much of the debate revolves around how the government can guarantee services to all citizens while minimizing costs and retaining incentives for high quality and on-time provision.

The formula PPP first emerged in the United Kingdom as an answer to this question, in the wake of the conservative revolution of Margaret Thatcher. Beginning in the early 1990s, the government began to explore avenues of co-production of public services with the private sector. PFI, as it was called in the UK (Private Financing Initiative) spread quickly across sectors and took various forms, depending on the exact role that each project assigned to the private and public sectors. The three main classifications that have emerged over time are summarized in Table 1 below. 
Table 1: PPP Project Types and Modalities

\begin{tabular}{|c|c|}
\hline $\begin{array}{ll} & \text { Modality } \\
\end{array}$ & Type \\
\hline $\begin{array}{l}\text { Type I: Variants of design-build-finance-operate where the private } \\
\text { sector designs, builds owns, develops, operates and manages an asset } \\
\text { with no obligation to transfer ownership to the government }\end{array}$ & $\begin{array}{ll}- & \text { Build-Own Operate (BOO) } \\
- & \text { Build-develop-operate (BDO) } \\
\text { - } & \text { Design-construct-manage-finance (DCMF) }\end{array}$ \\
\hline $\begin{array}{l}\text { Type II: The private sector buys or leases an existing asset from the } \\
\text { government renovates, modernizes and/or expands it and then operates } \\
\text { the asset. The private sector has no obligation to transfer ownership } \\
\text { back to the government. }\end{array}$ & $\begin{array}{ll}- & \text { Buy-build-operate (BBO) } \\
- & \text { Lease-develop-operate (LDO) } \\
- & \text { Wrap-around-addition (WAA) }\end{array}$ \\
\hline $\begin{array}{l}\text { Type III: The private sector designs, builds and operates and then } \\
\text { transfers the asset back to the government at some specified time. } \\
\text { After transfer the private sector may rent or lease the asset from the } \\
\text { government. }\end{array}$ & $\begin{array}{ll}- & \text { Build-operate-transfer (BOT) } \\
- & \text { Build-own-operate-transfer (BOOT) } \\
- & \text { Build-rent-own-transfer (BROT) } \\
- & \text { Build-lease-operate-transfer (BLOT) } \\
- & \text { Build-transfer-operate (BTO) }\end{array}$ \\
\hline
\end{tabular}

Adapted from: International Monetary Fund, "Public-Private partnerships", March 2004

What is unique about PPP in contrast to privatizations or traditional public procurement is that both the private sector and the government retain a role in this "marriage" during the life of the project. For the private sector, responsibility is not limited only to delivery of an asset, but to continuing provision of a service at acceptable quality levels over periods typically ranging up to 30 years. For the government, PPPs mean a level of involvement well beyond that of privatizations or even subcontracting or outsourcing, as the two sectors become long-term partners in the provision of high-quality services.

As PPP has broadened and expanded, a growing body of evidence has become available on what its benefits really are. The advantages in terms of higher quality or more technologically advanced services are difficult to quantify. In terms of costs and on-time delivery, the picture is clearer. Two major surveys of PPP projects conducted by the British government ${ }^{1}$ estimated average savings of $17 \%$ on the completed projects, due mainly to the avoidance of cost overruns in the construction phase. They also discovered that $80 \%$ of PPP projects had met their initial delivery time targets, compared to $20 \%$ for comparable public-sector projects ${ }^{2}$. The reports concluded that the main source of the savings was that risks of delays or overruns had effectively been transferred from the public to the private sector. This effective reallocation of risks is the main benefit of PPPs and is the issue that must be addressed most effectively when PPP contracts are negotiated.

In addition to cost savings, PPPs offer other financial benefits to the governments that use them as an alternative to traditional public procurement. They allow governments to spread out the costs of a project and to pay for a service only as it is provided. This additional flexibility and the savings detailed above usually more than outweigh the higher costs of private-sector financing of projects. Beyond the financial benefits, PPPs also offer the obvious advantages of private-sector management and experience in designing, constructing and delivering services that are often complex and increasingly specialized, and outside the scope of public-sector experience. An added plus is that private-sector suppliers who factor maintenance costs into a project (which is normally the case) are likely to plan and design projects more effectively.

Besides the benefits outlined above, a striking lesson of the UK experience with PFI/PPP is that a new role for the public sector has emerged, piece by piece, as experience has progressed. Rather than abdicating responsibility for the provision of public services, as it might have done with privatization, through PPP the government has become a long-term partner with the private sector and assumed new management responsibilities. Again, the UK was a pioneer in recognizing, defining and implementing these new governmental responsibilities. It created a government unit dedicated to PPP that was active in providing advice to departments or governments that were contemplating private-sector involvement in public service delivery. It developed the Public-Sector

\footnotetext{
${ }^{1}$ NAO 2001 and HM Treasury 2003.

${ }^{2}$ HM Treasury, "PFI: Meeting the Investment Challenge", Crown Copyright, July 2003.
} 
Comparator, an interactive model that enables potential users of PPP to compare the cost of a project by public and private-sector providers, so that rational decisions can be made ${ }^{3}$. It drafted model contracts for different types of projects and encouraged small projects to consolidate under a single umbrella contract, to assist government units that had less experience with PPP and reduce the transaction costs involved in the bidding process. It developed an exhaustive list of the PFI projects undertaken throughout the UK, which made available to the public all relevant information on each project ${ }^{4}$. And it became active in following up projects in order to evaluate the performance of PPP and learn from its successes and failures.

As PPP became widely accepted and spread to new sectors and countries, the need to provide these services and develop public-sector management skills became an international concern. The concern is especially pressing in countries undergoing major political and social change, such as developing countries and Eastern Europe. The PPP unit of the United Nations Commission for Europe has been active in outlining the responsibilities that governments should assume for good governance of PPP projects. Among these responsibilities are providing an adequate legal framework, informing citizens and maintaining transparent processes, ensuring a level playing field for potential bidders, avoiding corruption and defining and monitoring the performance of the private partners 5 . (An extensive list of these responsibilities is included in Appendix 1 of this paper, in the form of a proposed "scorecard" of how well governments are managing PPP.)

\section{THE SPANISH EXPERIENCE WITH PPP}

Spain was not a newcomer to PPP when projects involving cooperation between the public and private sectors began to spread in size and variety at the end of the 1990s. There are records of privately constructed highways in Spain in the $19^{\text {th }}$ century, and former dictator Francisco Franco used a simple form of BOT successfully in the 1970s to construct numerous toll highways. It appeared natural for Spain to explore the PPP option under the conservative government that came to office in 1996, whose platform focused on deregulating and privatizing the economy.

The first PPP projects in Spain in the 1990s were in the traditional transport sector, particularly highways. The volume of these projects soared at the end of the 1990s (see Figures 1, 2 and 3 below). At the same time, their characteristics began to change: they spread to new sectors, beginning with health; and the contracting party shifted from the national government to the many (17) regional governments in Spain's decentralized system. (see Figures 4, 5 and 6 below) In 2005, the regional governments monopolized the PPP market in Spain, and projects were being negotiated and signed in waste management, construction of public buildings and especially health. In both volume and diversification, Spain in 2006 resembled the main EU countries that employed PPP; and it was a leading country in the EU in terms of project volume in 2003-2004 and 2004-2005 (Figures 7 and 8). ${ }^{6}$ Under the Infrastructure Plan unveiled by the PSOE in 2005, the government plans to obtain from the private sector $40 \%$ of a total financing of $€ 241.4 \mathrm{bn}$ until the year 2020 for new and improved highways, railways, airports, ports and other infrastructures. This would be equivalent to about $0.5 \%$ of Spanish GDP per year until 2020, and would represent an unprecedented role for PPP in Spain that would make it a leader in Europe.

\footnotetext{
${ }^{3}$ See Treasure Taskforce Private Finance, Technical Note $n^{o}$ 5: How to Construct a Public Sector Comparator, October 1999, p. 17. An example of an interactive PSC developed by the Dutch government can be seen at http://www.minfin.nl/PPS.

${ }_{5}^{4}$ See this list at Project database Partnerships UK: http://www.partnershipsuk.org.uk/projectsdatabase/projectshome.html

5 Governance in Public Private Partnerships for Infrastructure Development (Draft), Economic Commission for Europe, Committee for Trade, Industry and Enterprise Development, Working Party on International Legal and Commercial Practice (WP.5), October 2005.

${ }^{6}$ European PPP Report 2005, DLA Piper Rudnick Gray Cary
} 
Figure 1

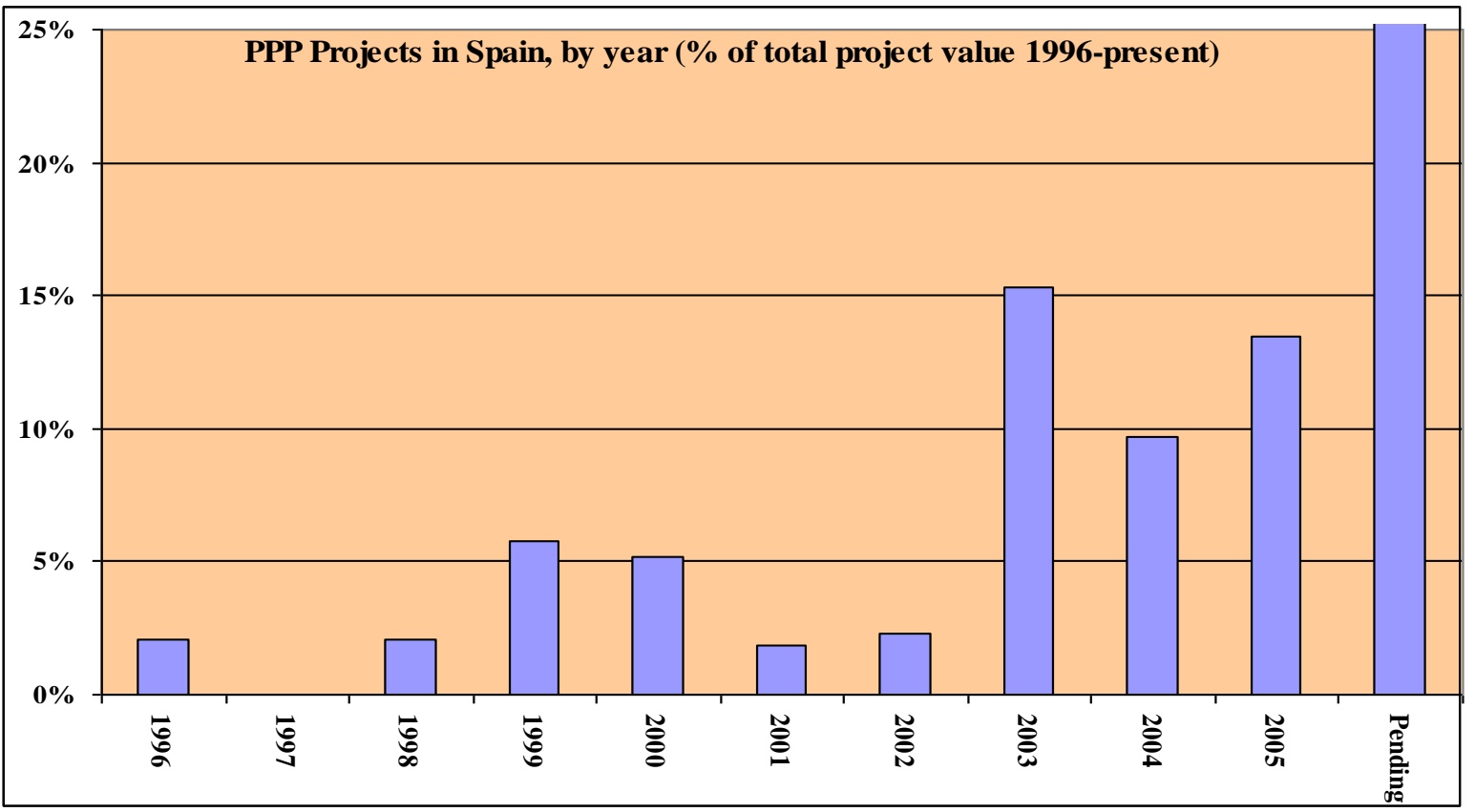

Figure 2

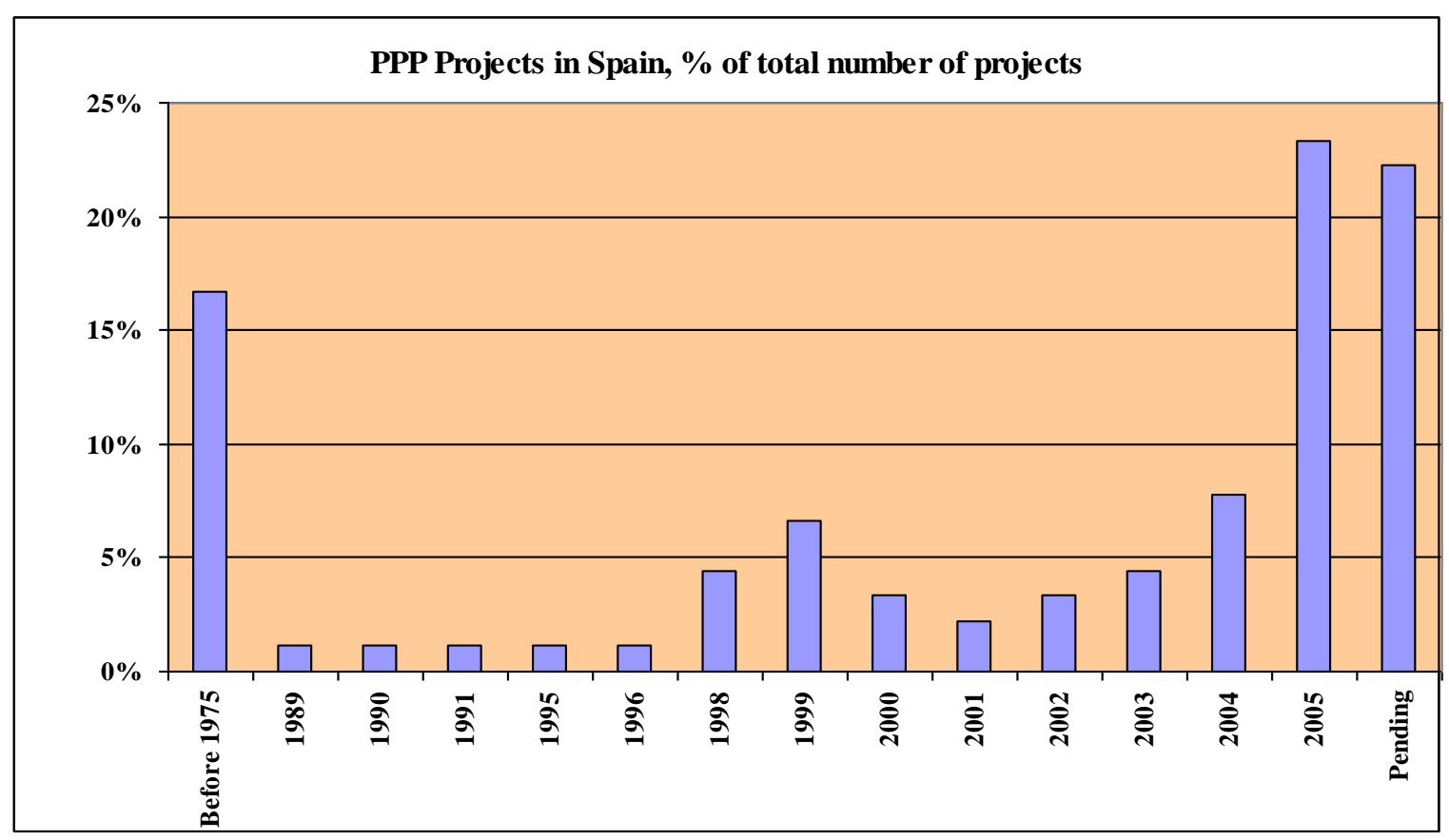


Figure 3

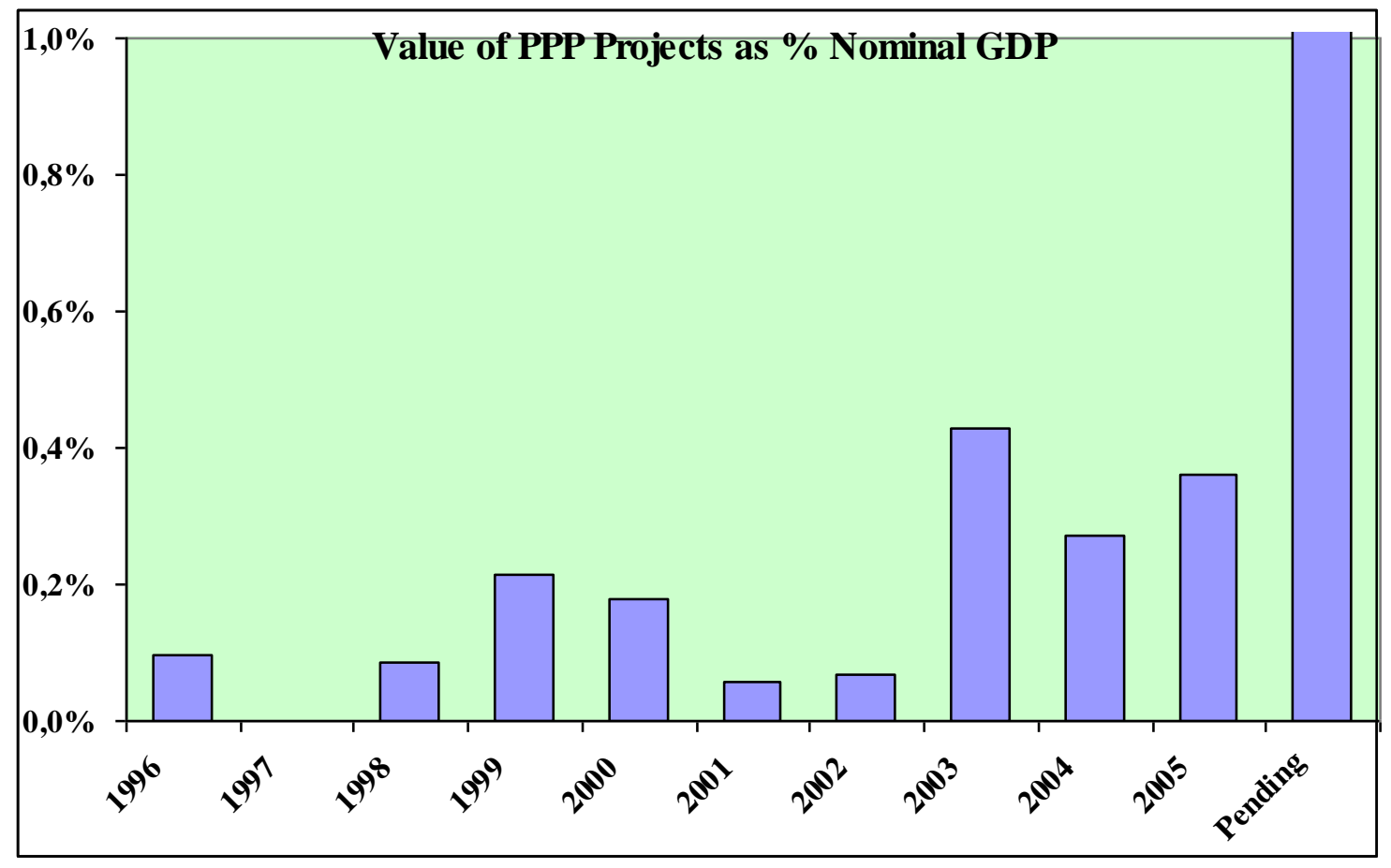

Figure 4

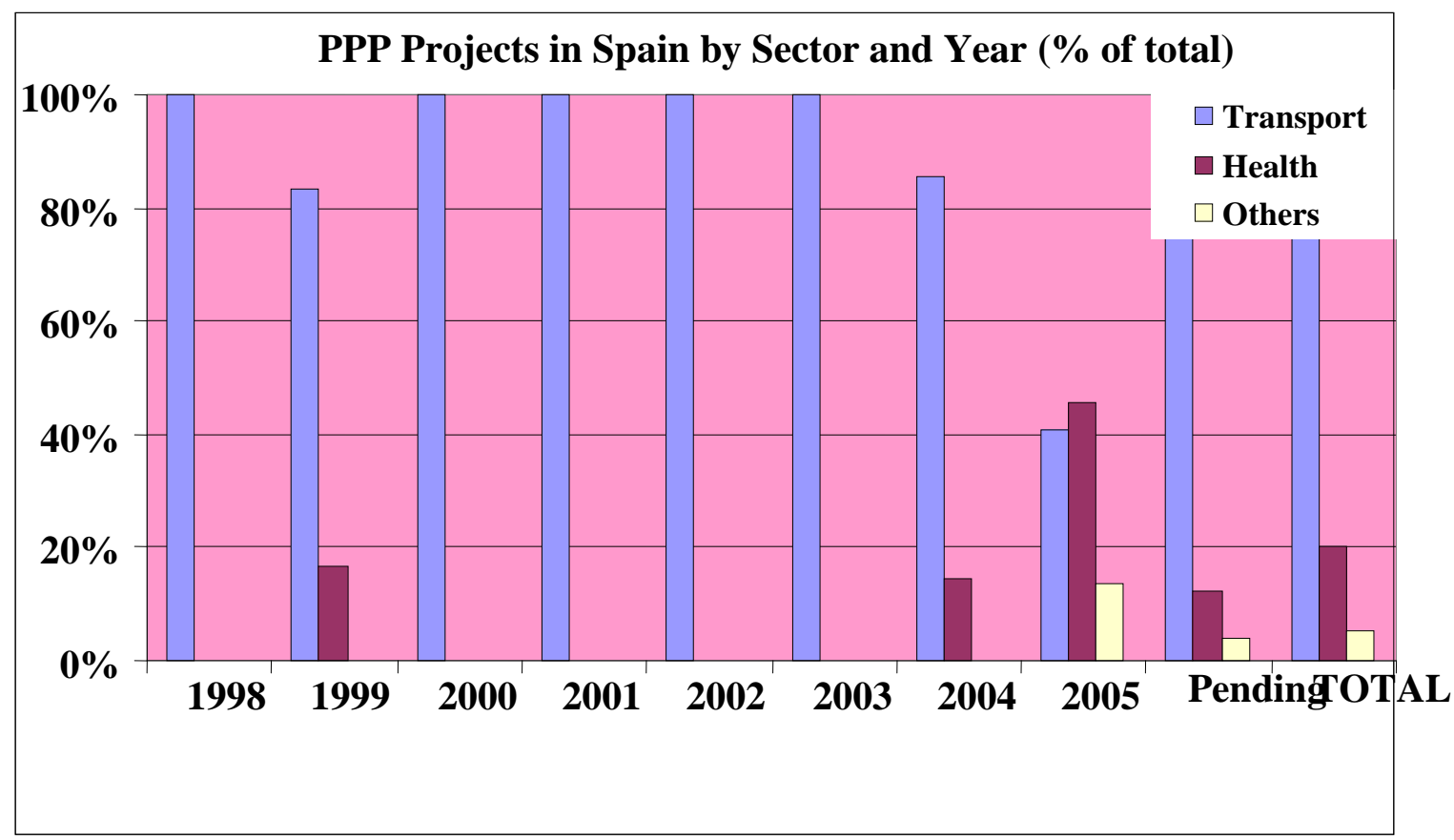


Figure 5

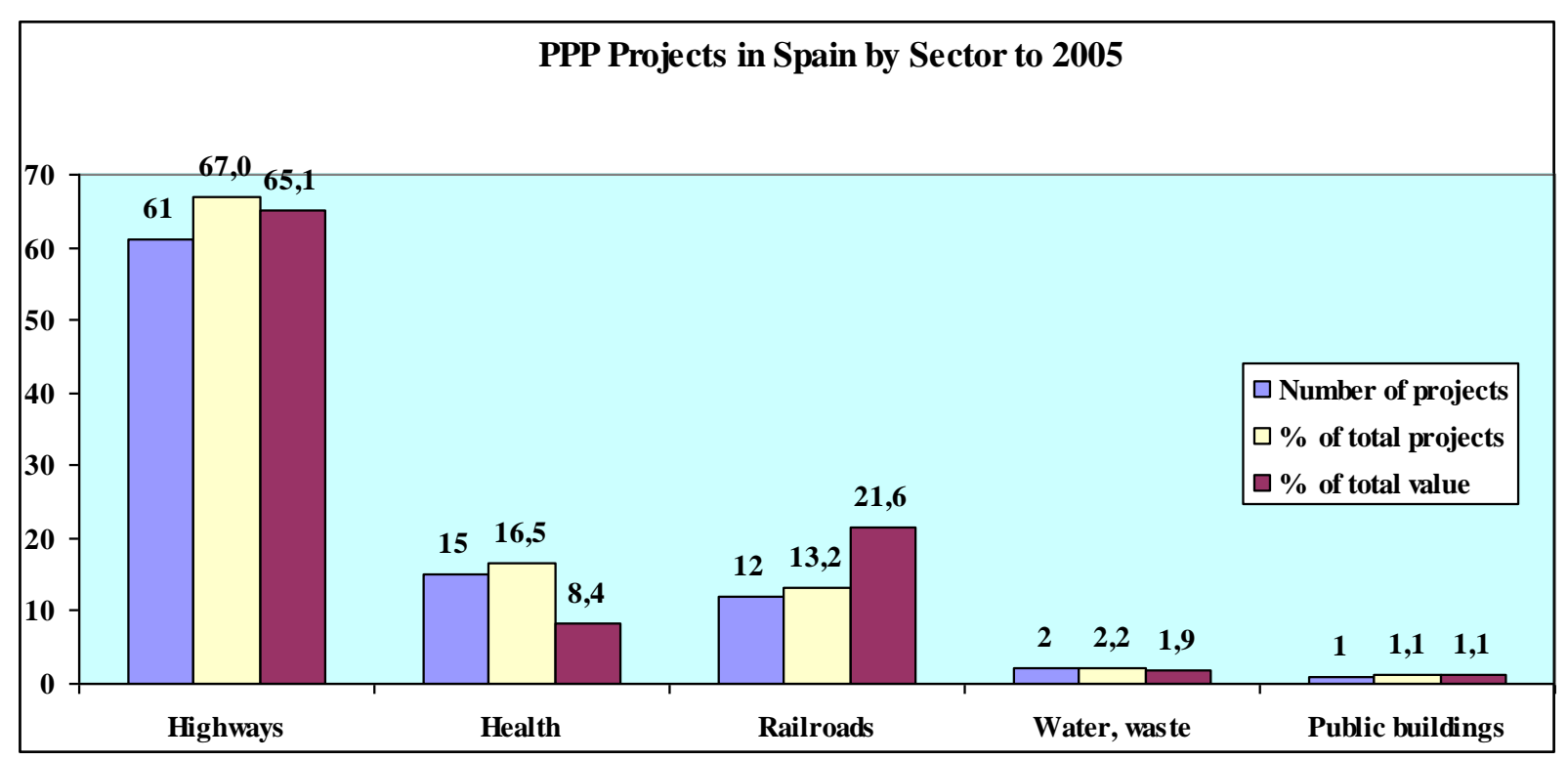

Figure 6

\section{Entidad Contratante}

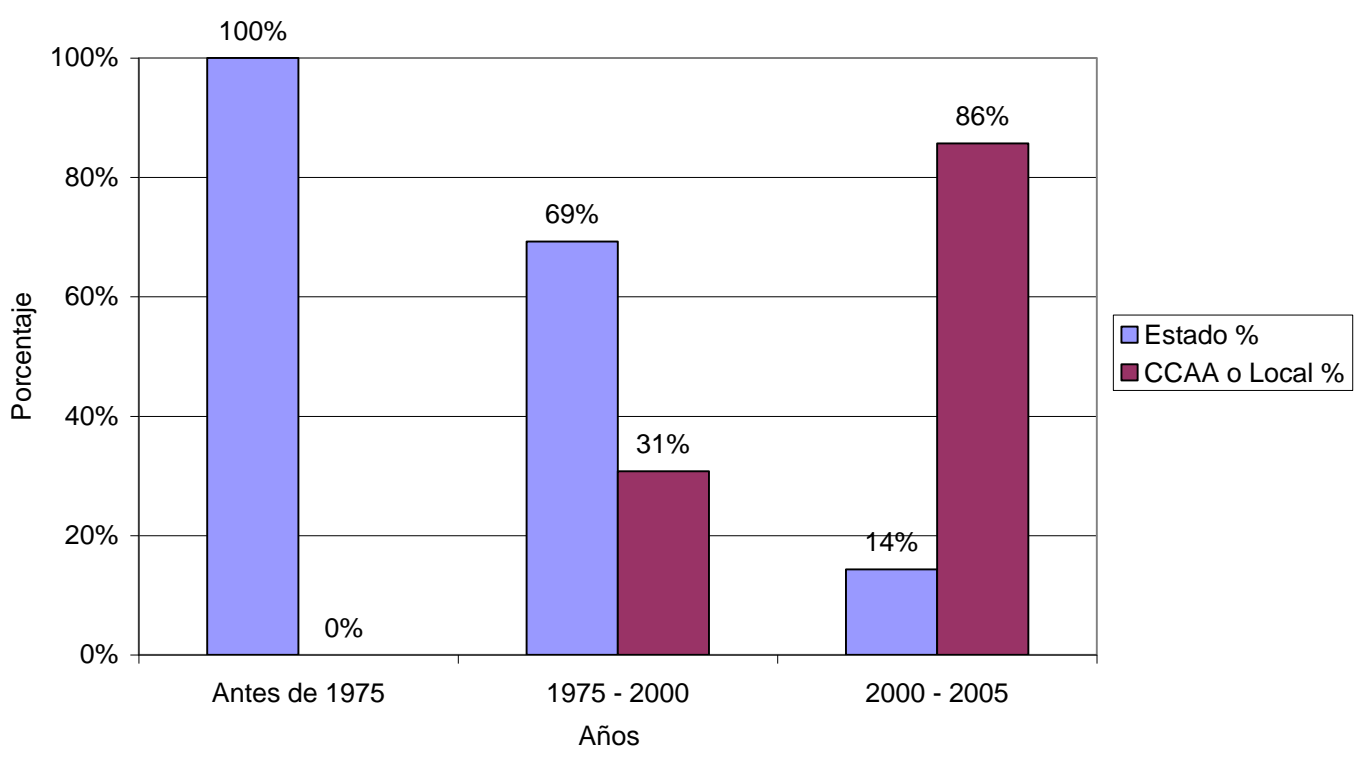


Figure 7

PPP Projects Pending in EU Countries in 2005, by Sector (\% total)

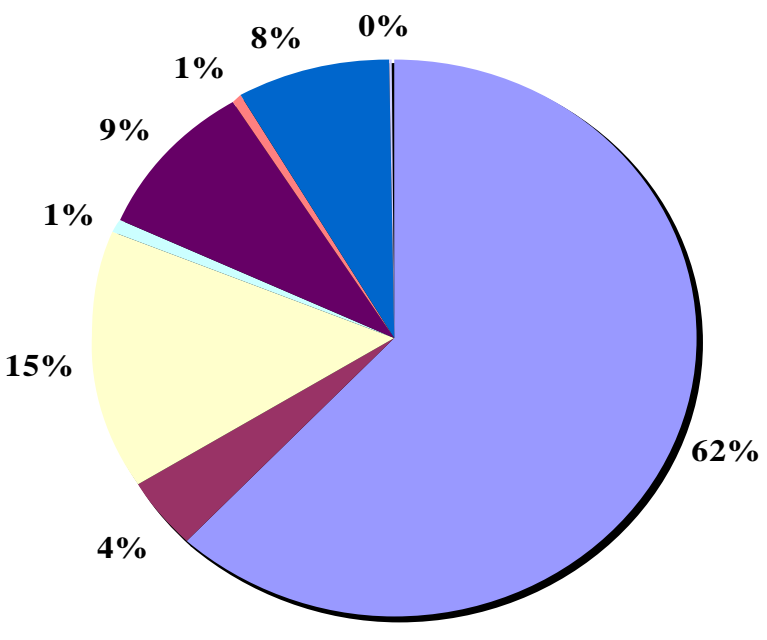

Highways

- Public buildings Railroads

Education

- Health

Leisure

Information tech.

Airports

Figure 8

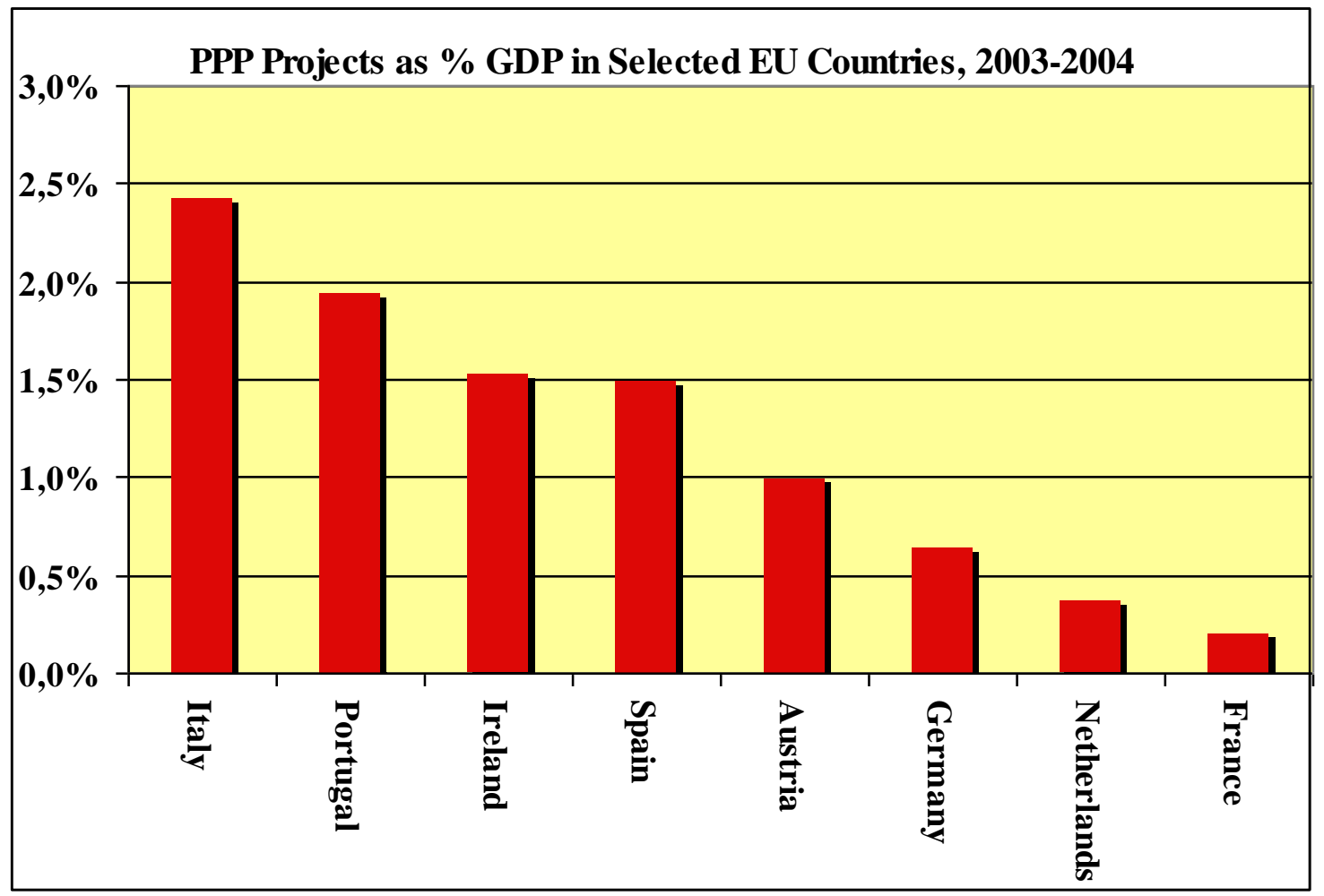


What has driven this explosive development of PPP in Spain? Undoubtedly, the Popular Party that governed Spain from 1996 to 2003 and currently governs many regions sympathizes with a view of PPP as the most efficient vehicle to deliver high-quality public services at lower cost, through the involvement of more efficient private sector partners. However, on an official level this view has not been clearly and publicly articulated. This has led to confusion in the public debate over the meaning and content of PPP. Under the Socialist party (PSOE) that took office in 2003, use of PPP at a national level has accelerated, and the public discussion mentions only the advantages of obtaining additional private-sector financing.

It is significant that the surge in Spanish PPP projects coincides with 1) the Maastricht Treaty and the fiscal restraint demanded by its criteria for euro membership and 2) the expected drop in EU structural and cohesion funds to Spain following the enlargement of the European Union, which have been the source of financing for many Spanish infrastructure projects. It seems fair to say that the main force -and possibly the only one-- propelling PPP in Spain over the past decade has been to obtain additional financing at a time of budget constraints and need for improved infrastructures and services.

This exclusive emphasis on financing has conditioned the Spanish approach to managing PPP. Rather than articulating a strategy and supporting it with specific guidelines to obtaining value for money and negotiating acceptable contracts, the government's approach could be better described as a "hands off" search for private financing. At the time of this report, a specific PPP unit still did not exist in the Spanish government, making it unique among the European Union countries. Nor was there PPP-specific legislation, apart from the Infrastructure Law that was enacted in 2003 to regulate various aspects of privately funded projects. The government has not made model contracts available to its different ministries or levels of government, and no public-sector comparator has been developed or adapted that could be used to determine whether using the PPP formula for a project offered potential value for money. The Spanish government has not even made an official register of PPP projects available to citizens; in fact, the list given in Appendix 2, developed by the authors of this report, is the most comprehensive register developed in Spain. And at the date of this report, there had been no comprehensive official follow-up made available to the public of the many PPP projects undertaken in Spain, along the lines of the surveys described above for the UK. The Spanish government has relied almost exclusively on the market and private initiative to achieve the benefits of PPP for its citizens. It shows little evidence of having accepted its role as active public manager and partner in a new formula of provision of public services, along the lines set out by the UK or the UNECE guidelines for PPP governance.

What are the risks inherent in this approach to PPP, in contrast to the more "hands-on" British approach? Probably the main risk is that without a public-sector comparator or official support for negotiation of complex projects, there is no guarantee that PPP is the best alternative for provision of public services. The experience of the UK and other countries has demonstrated that PPP is not appropriate for all projects; and that there are times when full public provision of services is a more efficient approach. Choosing PPP without carefully contrasting the public and private costs for each project may turn out to be a more costly option for taxpayers and the final users of the services provided by PPP.

Added to this risk is the danger that PPP projects that are not carefully monitored may not fulfill the expected quality standards, or may experience cost overruns that are charged back to the public sector or to the final user. The Spanish bidding process has been characterized by fierce competition for projects, which often result in aggressive pricing and discounts of up to $30 \%$ over the initial projected $\operatorname{cost}^{7}$. It seems evident that Spanish companies are eager to win these projects, which guarantee annual streams of income over long periods, and are willing to slash prices in order to do so. However, the implicit risk in awarding a contract to an underpricing bidder is that if the offer is too low and the company cannot cover costs, it will either deliver a lower-quality service than initially expected or pressure the government to renegotiate the contract at a higher price. Either option shortcircuits the benefits from PPP.

\footnotetext{
${ }^{7}$ Since the government does not maintain an official project register available to the public and details of biddings are not always publicly available, this is not an official figure but an estimate by Tecniberia-Asince, an industry association of engineering and consulting firms.
} 
The fact that Spain does not yet perform comprehensive follow-up or even maintain a central register of PPP projects underlines another risk inherent in the "hands-off" approach: that PPP projects may not be delivering value for money over the medium and long term, and the government is missing valuable opportunities to review its experience, correct errors and learn from its mistakes. As PPP activity decentralizes and accelerates at regional and local levels of government, authorities entering into complex negotiations may be doing so without the tools that are necessary to guarantee that the projects deliver value for money. Again, the risk inherent in this approach is either renegotiation at higher prices in the future, lower quality services or the inviability of projects over the medium and longer term.

Finally, in Spain there has been no official effort to inform the public on the motives for PPP and its potential benefits. In contrast to the efforts for transparency and effective communication of objectives and results in the UK, very little public relations effort has been associated with PPP in Spain at any level of government. The risk inherent in this failure to articulate and communicate a role for PPP is that employees involved in new projects or final users who do not see the benefits of private-sector provision may begin to voice their opposition to PPP. This would raise the risk of private investment in PPP projects, which could mean lower investor interest in new projects and higher costs. Again, the ultimate risk is that PPP will not deliver its potential benefits to taxpayers and users in Spain.

What can be done to avoid these risks? In light of the international experience and the particular characteristics of Spain's history with PPP, the following changes would be important steps forward to guide the process in Spain:

1. A clear and specific framework should be elaborated for the PPP bidding process in Spain. This should include not only laws, which are largely adequate, but a public-sector comparator, model contracts for complex projects and steps to ensure that the playing field in Spain remains level and open to foreign bidders.

2. A PPP unit must be created at the national level to monitor, oversee and review projects, to ensure that their potential benefits are realized and communicated to the public.

3. The public sector must accept its management or "governance" role in PPP, along the lines envisaged by the UNECE or demonstrated by the governments of the UK and other countries that have utilized PPP.

4. A strategic vision for PPP that crosses party lines should be elaborated by the government and communicated clearly to citizens. This would ensure continued support for projects and lend security to potential investors into the longer term.

PPP can be an asset or a potential liability to the governments that use it, depending on how successfully they are managed. Spain faces a significant public management challenge as PPP activity surges in all sectors and at all levels, and the way it responds to the challenge will determine whether PPP delivers its proven benefits to Spanish citizens in the form of lower-cost, higher-quality public services.

\section{SELECTED BIBLIOGRAPHY}

1. Abadie, R., \& Howcroft, A. (2004). Developing Public-Private Partnerships in New Europe. Price Waterhouse Coopers.

2. Allen, G. (2001). The Private Finance Initiative (PFI). House of Commons Library. (Research Paper 01/117)

3. Aparicio Mourelo, A. (2005). Putting Transport Infrastructure at the Service of Sustainable Transport. PPP in Spain SMI Conference Documentation.

4. Arana, J. M. (2005). Latest Developments in Spanish Road Financing. PPP in Spain SMI Conference Documentation.

5. Arthur Anderson and Enterprise LSE. (2000). Value for Money Drivers in the private Finance Initiative. Report commissioned by Treasury taskforce. 
6. Asian Development Bank Staff. (2000). Developing Best Practices for Promoting Private Sector Investment in Infrastructure. Asian Development Bank. Electronic preference formats recommended by www.Artery.org. Retrieved June 2005 from: (http://www.artery.org/AtlanticSteel.htm).

7. Auriol, E., \& Picard, P. (2004). Privatizations in Developing Countries and the Government's Budget Constraint. IDEI - Institut d' Economie Industrielle.

8. Bartsch, C., Pepper, E., \& Collaton, E. (1996). Coming Clean for Economic Development: A Resource Book on Environmental Cleanup and Economic Development Opportunities. Northeast - Midwest Institute.

9. Bel, G., \& Fageda, X. (2005). Is a mixed funding model for the highway network sustainable over time? The Spanish Case. Forthcoming in Ragazzi, G. i W. Rothengatter (Eds.), Procurement \& Financing of Motorways in Europe. JAI press.

10. BOT Expert Group. (1998). Public-Private Partnerships: A new Concept for Infrastructure Development. Economic Commission for Europe, United Nations Publication.

11. Bousquet, F., \& Fayard, A. (2001, September). Road Infrastructure Concession Practice in Europe. World Bank World Bank Institute: Governance, Regulation and finance division (Policy research working paper 2675).

12. Brown, G. (2003). Public Private Partnership in UK Roads Sector. Halcrow, from http://ncppp.org/councilinstitutes/texas_presentations/brown.pdf

13. Brusewitz, M. R. (2004/2005). Public-Private Partnerships in the United States (Electronic version). ProjectFinance Legal Advisors Review, 70-71.

14. Caja Madrid. (2002). Financing Transportation Infrastructure in Spain: Successful Schemes and Case Studies. Caja Madrid - U.S. - Spain Forum on Transportation \& Housing Finance. Carson, S. (1999). Justifying Global privatization: Economics, Public Policy and Education. ABAS Conference.

16. Centro PWC \& IE Sector Público, Instituto de Empresa, \& PricewaterhouseCoopers. (2005). Externalización de la Gestión y la Financiación del Sector Público en España. Madrid: LID Editorial Empresarial, S.L.

17. Claverley, J. (2005). The business case: The healthcare infrastructure Programme of the Community of Madrid. PPP in Spain SMI Conference Documentation.

18. Colindres, R., \& de Parias, C. (2004/2005). Autovía de Camino: First Monoline-wrapped Spanish Public Shadow Toll Road. Euromoney Transportation Finance Review.

19. Cox, D., Moleanaar, K., Ernzen, J., Henk, G., Matthews, T., Smith, N., Willams, R., Gee, F., Kolb, J., Sanderson, L., Wited, G., Wight, J., Yakowenko, G. (2002). Contract administration: Technology and practice in Europe. Federal Highway Administration.

20. Croome, C. (2003). Private Finance Initiative and Public Private partnerships: What Future for Public Services. Center for Public Services.

21. De Luca, A. (2000). An Economic and Financial Analysis of Public Private partnerships. National Library of Canada.

22. DH, Department of Health. (2002). Good Practice Guide: Learning Lessons from post-Project Evaluation.

23. Demirag, I., Dubnick, M., \& Khadaroo, I. (2004). A Framework for Examining Accountability and Value for Money in the UK's Private Finance Initiative. Journal of Corporate Citizenship, 15: 63-76.

24. Department of Health Private Finance Unit. (2003). PITN Guidance Notes (Version 2).

25. DLA Piper Rudnick Gray Cary. (2002). European PPP Report 2002, from: http://www.dlapiper.com/

26. DLA Piper Rudnick Gray Cary. (2003). European PPP Report 2003, from: http://www.dlapiper.com/

27. DLA Piper Rudnick Gray Cary. (2004). European PPP Report 2004, from: http://www.dlapiper.com/

28. DLA Piper Rudnick Gray Cary. (2005). European PPP Report 2005, from: http://www.dlapiper.com/es/global/publications/detail.aspx?pub=1337

29. Dornan, D. (2001). Abstract Asset Management-Management Fad or Prerequisite for solving the fiscal challenges facing highway infrastructure. Infrastructure Management Group.

30. ENA Infraestructuras, S.A. http://www.ena.es/otrpoy.htm

31. European Commission. Directorate-General Regional Policy. (2003). Guidelines for Successful PublicPrivate Partnerships.

32. European Commission. (2004). Green Paper on Public-Private Partnerships. 
33. Fatás Monforte, J.M., Magide Herrero, M., \& Massó G. (2005). Informe sobre Modelos de Cooperación Publico-Privado para Financiación de Infraestructuras Publicas: Tratamiento en Términos de Contabilidad Publica (SEC 95) y Viabilidad Jurídica. Price Waterhouse Coopers and Uria \& Menéndez.

34. Fayard, A. (1999). Seminar on Public private partnerships (PPP's) in Transport Infrastructure Financing. Paris: European Conference of Ministers of Transport.

35. Ferrovial. (2002). Privatization of Transportation Infrastructures Examples of Value Optimization. US Spain Forum on Transportation \& Housing Finance.

36. Finlay, D. (2003). Keeping a Close Eye on PFI. Government Opportunities: Facilitating Business with Government, de http://www.govopps.co.uk

37. Gerrard, M. (2001). Public-Private Partnerships: What are public-private partnerships, and how do they differ from privatizations? Finance and Development, 38, (3).

38. HM Treasury. (2003). PFI: Meeting the Investment Challenge. U.K.: The Stationery Office.

39. HM Treasury. (2002). Supplementary Green book Guidance Adjusting for Taxation in PFI vs PSC Comparisons. Crown Copyright

40. HM Treasury. (2004). Standardization of PFI Contracts Version 3. Crown Copyright.

41. HM Treasury. (2004). Value for Money Assessment Guidance. Crown Copyright.

42. Hospital Employee's Union. (2001). Sustainability through Reform not Privatization: The Problem of Relying on the Private Sector for New Health Care Infrastructure Developments.

43. Instituto Nacional de Estadística (INE). http://www.ine.es/

44. International Financial Services. (2003). PFI in the UK: Progress and Performance. PPP Brief.

45. International Financial Services. (2003). Private Public Partnerships UK Expertise for International Markets.

46. International Monetary Fund. (2004). Public-Private Partnerships.

47. Jacobson, C., \& Tarr, J. (1995). Ownership and Financing of Infrastructure: A Historical Perspective. The World Bank . (Policy Research Working paper 1466).

48. KPMG. (2003). Module 2: Guide to the PPP Procurement Process. KPMG LLP.

49. Lopez Corral, A. (2002). Spanish Experience in Supplying and Financing Infrastructures. US / Spain Forum on Housing and Transportation Finance.

50. Menendez, L. S. (2002). Public/Private Partnerships and Innovation policy: The Spanish Experience. Presented at Joint Mexico-OECD Conference on International Public/Private partnerships for Innovation.

51. Middleton, N. (1999). Public Private Partnerships - A Natural Successor to Privatizations. PwC Global.

52. Ministerio de Economía y Hacienda. (2005). Presupuestos Generales del Estado. Introducción y Estructuras Presupuestarias, from: http://www.igae.meh.es/Internet/Cln_Principal/

53. Ministerio de Fomento. (2004). Plan Estratégico de Infraestructuras y Transporte, from http://peit.cedex.es/

54. Ministerio de Hacienda - Instituto de Estudios Fiscales. (2004). Informe y Conclusiones de la Comisión de Expertos para el Estudio y Diagnostico de la Situación de la Contratación Pública.

55. Ministry of Finance. PPP Knowledge Center. (2002). Public Private Comparator.

56. Moreno, J. A., Pleite, F. (2003). Análisis de la Nueva Ley Reguladora del Contrato de Concesión de Obras Públicas.

57. Moulton, L., \& Anheier, H. (2001). Public-Private Partnerships in the United States: Historical Patterns and Current Trends. The Center for Civil Society. (Civil Society Working Paper 16).

58. Neville, T. (2002). PFI: Practical Perspectives. ACCA: International Accountancy Body UK.

59. NHS Trusts 2000 Buyer's and Commissioner's Guide. (2000). Implementing the Private Finance Initiative, Dr. Courtney Smith from the NHS Information Authority Offers Some Tips, from http://nhtrusts.com/pages_old/2000/feature_p69 01.htm

60. Price Waterhouse Coopers and Uria \& Menéndez. (2005). Informe CEOE sobre Modelos de Cooperación Público - Privada para la financiación de infraestructuras Públicas. Confederación Española de Organizaciones Empresariales.

61. $\quad$ Private Finance Unit. (2004). PITN Guidance Notes Version 2.

62. Rebollo Fuente, A. (2005). PPP in Healthcare Models and Structures for the Spanish Healthcare \& a Review on Upcoming Opportunities. PPP in Spain SMI Conference Documentation. 
63. Rebollo Fuente, A. (2005). Spanish Healthcare PPP: A Review on Structures and Opportunities. PPP in Spain SMI Conference Documentation.

64. Seader, D. (2002). The United States' Experience with Outsourcing, Privatization and Public-Private Partnerships. National Council for Public-Private Partnerships.

65. Smith, C. (2000). Implementing the Private Finance Initiative. NHS Trusts 2000 Buyers and Commissioners Guide.

66. Sturgess, G. (2003). Competition: a Catalyst for Change in the Prison Service, a Decade of Improvement. CBI - Confederation of British Industry.

67. Treasury Taskforce Private Finance. (1999). How to Construct a Public Sector Comparator. (Technical Note $n^{\circ} 5$ ).

68. UK National Audit Office. (2003). PFI: Construction Performance. (Controller and Auditor General HC 371).

69. UK Trade \& Investment, International Financial Services London (IFSL), \& British Consultants and Construction Bureau (BCCB). (2004). How to Access UK Expertise in Public Private Partnerships. A Brief Guide from UK Trade \& Investment (Electronic version). UK: UK Trade \& Investment.

70. United Nations Institute for Training and Research (UNITAR), \& Deutsche Management Akademie Niedersachsen (DMAN). (2001). Public-Private Partnership for Sustainable Development.

71. United Nations. Economic Commission for Europe. (1998). Public-Private Partnerships, A New Concept for Infrastructure Development.

72. United Nations Economic Commission for Europe. (2005). Governance in Public Private Partnerships for Infrastructure Development (Draft).

73. Utt, R. (1999). How Public-Private Partnerships Can Facilitate Public School Construction. Heritage Foundation.

\section{APPENDIX 1}

UNECE Scorecard For Successful Governance Of PPP Projects By The Public Sector

\begin{tabular}{|c|c|c|c|c|c|c|}
\hline \multicolumn{2}{|c|}{ Benchmarking } & \multicolumn{5}{|c|}{ Score } \\
\hline \multicolumn{2}{|c|}{ Transparency } & 1 & 2 & 3 & 4 & 5 \\
\hline \multicolumn{2}{|r|}{ Participation of citizens } & & & & & \\
\hline \multicolumn{2}{|r|}{ Consumers' organizations } & & & & & \\
\hline & involvement in projects & & & & & \\
\hline & Media exposure & & & & & \\
\hline & Proposal of projects by civil society and/or NGOs & & & & & \\
\hline & Use of constitutional tools for decision-making process & & & & & \\
\hline & inclusion of referendum in the Constitution & & & & & \\
\hline & regularity of its use & & & & & \\
\hline & level of citizens' awareness of its existence and purpose & & & & & \\
\hline \multicolumn{2}{|c|}{ Public Procurement } & & & & & \\
\hline & Selective procedure & & & & & \\
\hline & General applicable law for all tender processes & & & & & \\
\hline & Specific laws according to the sector & & & & & \\
\hline & Harmonized rules under regional unification initiatives & & & & & \\
\hline
\end{tabular}




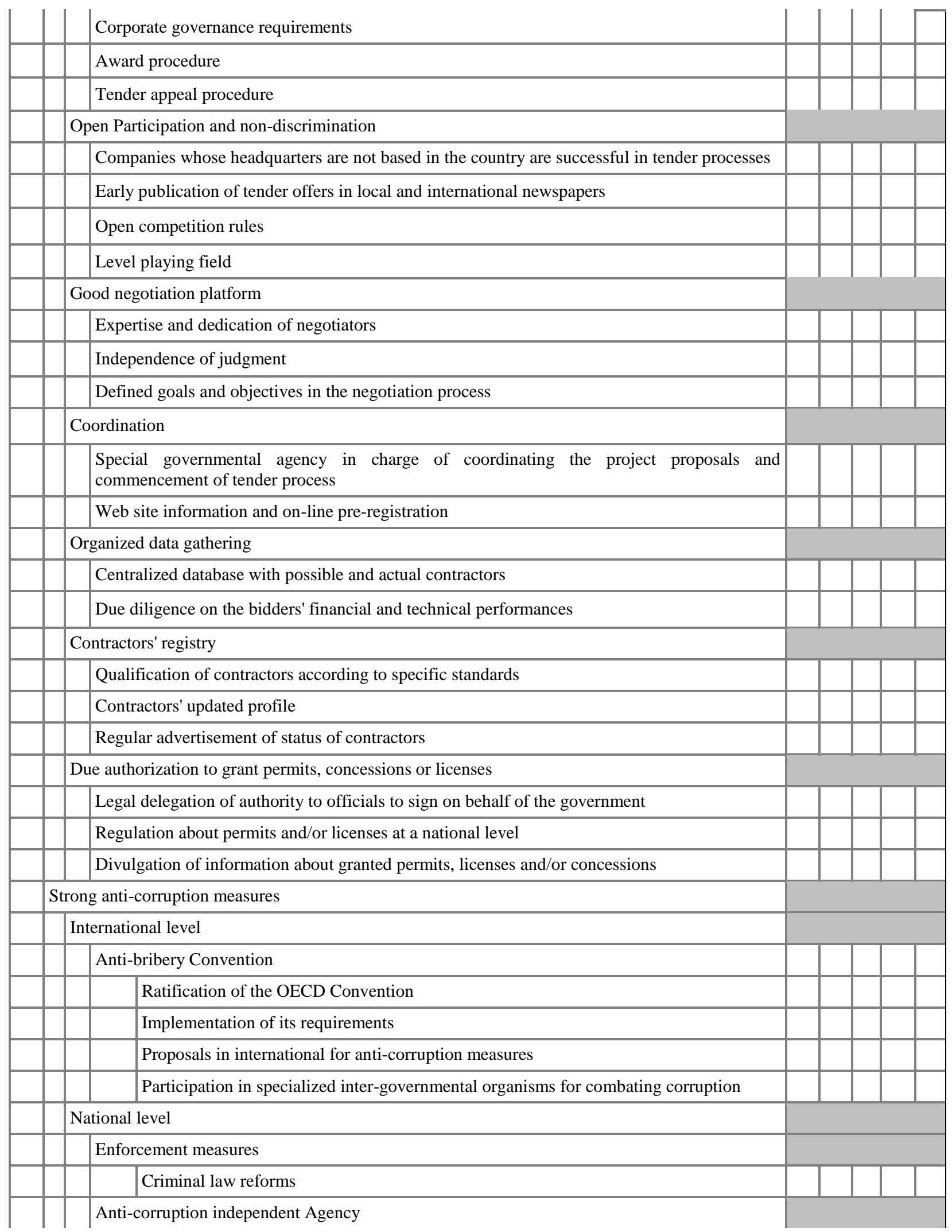




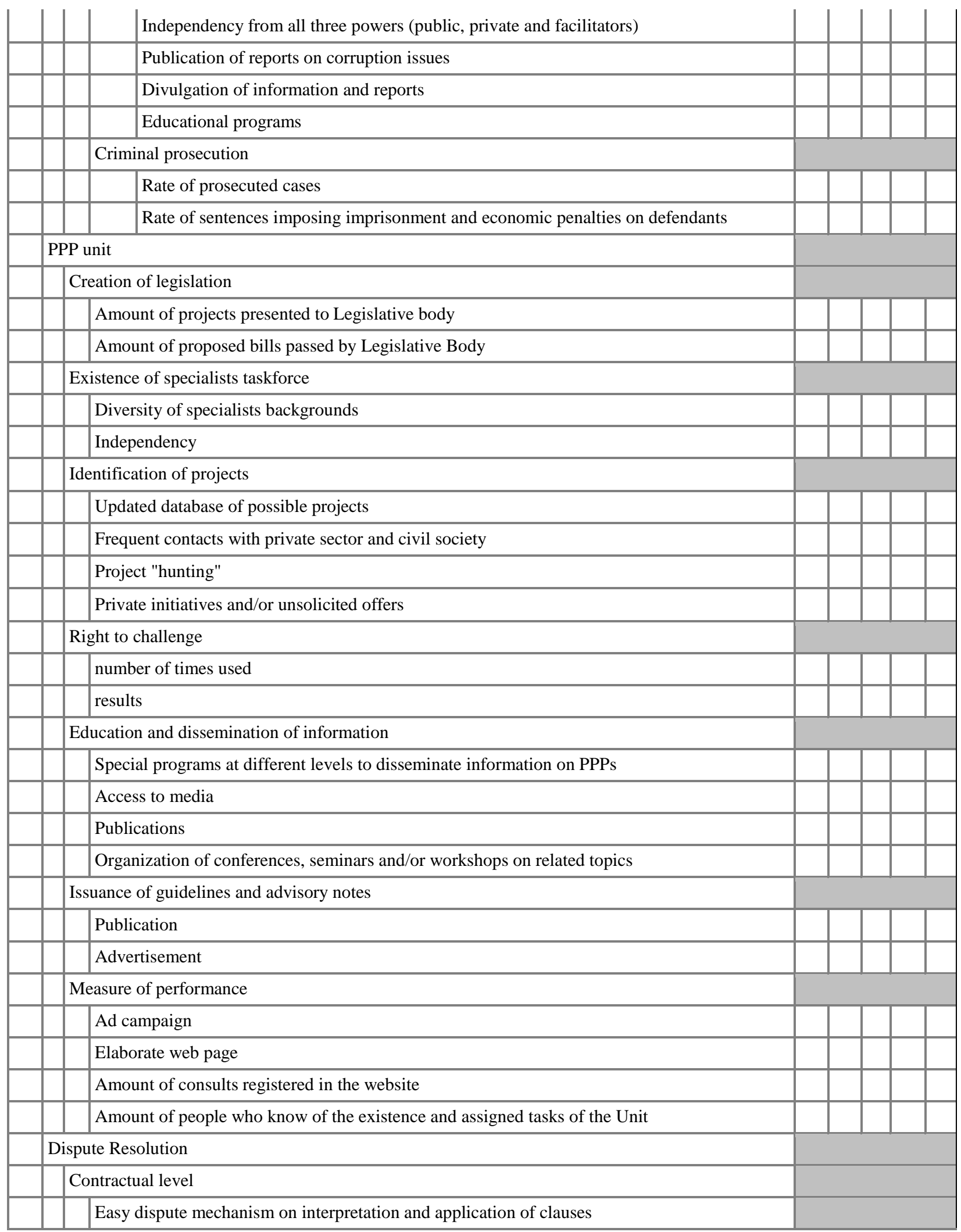




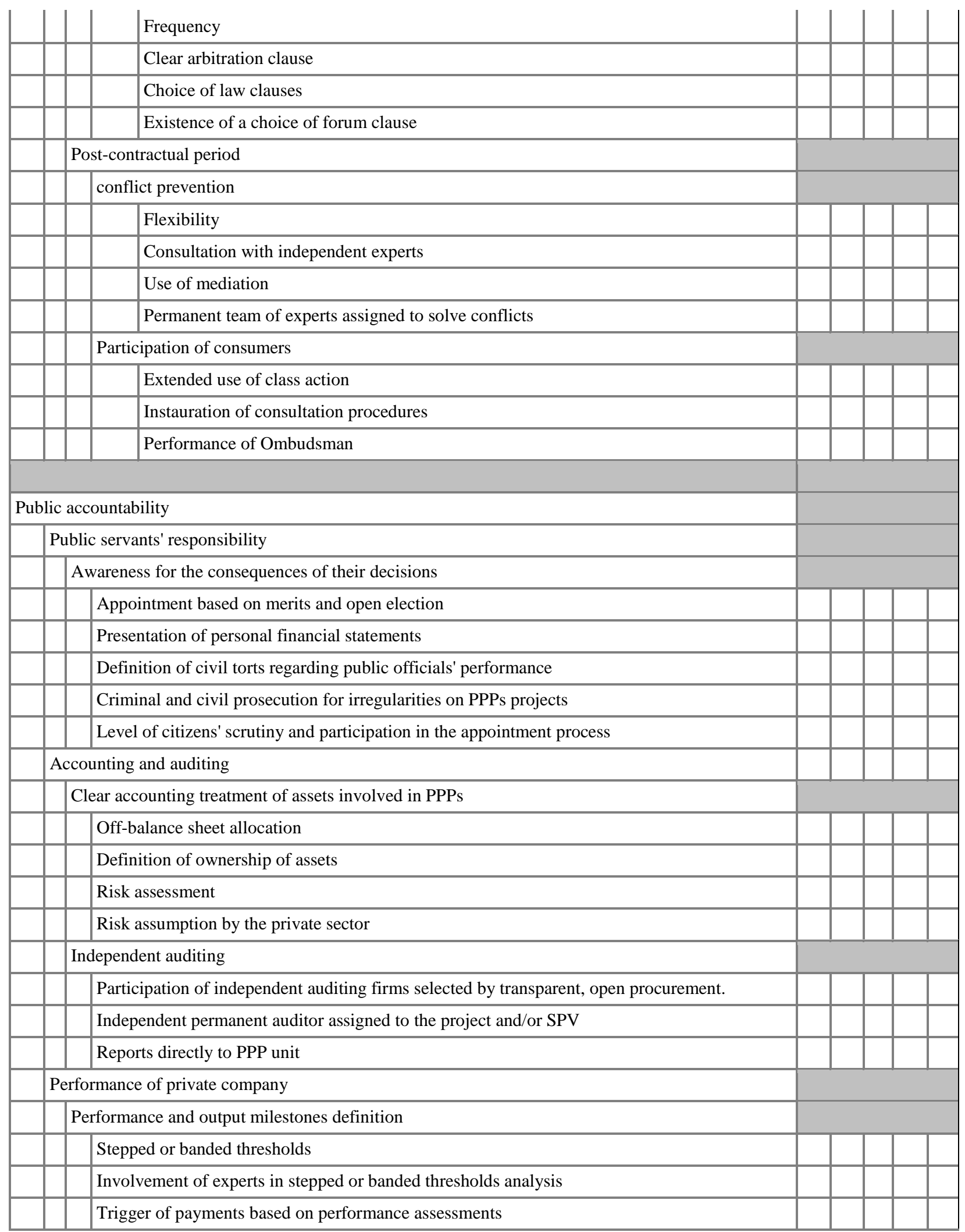




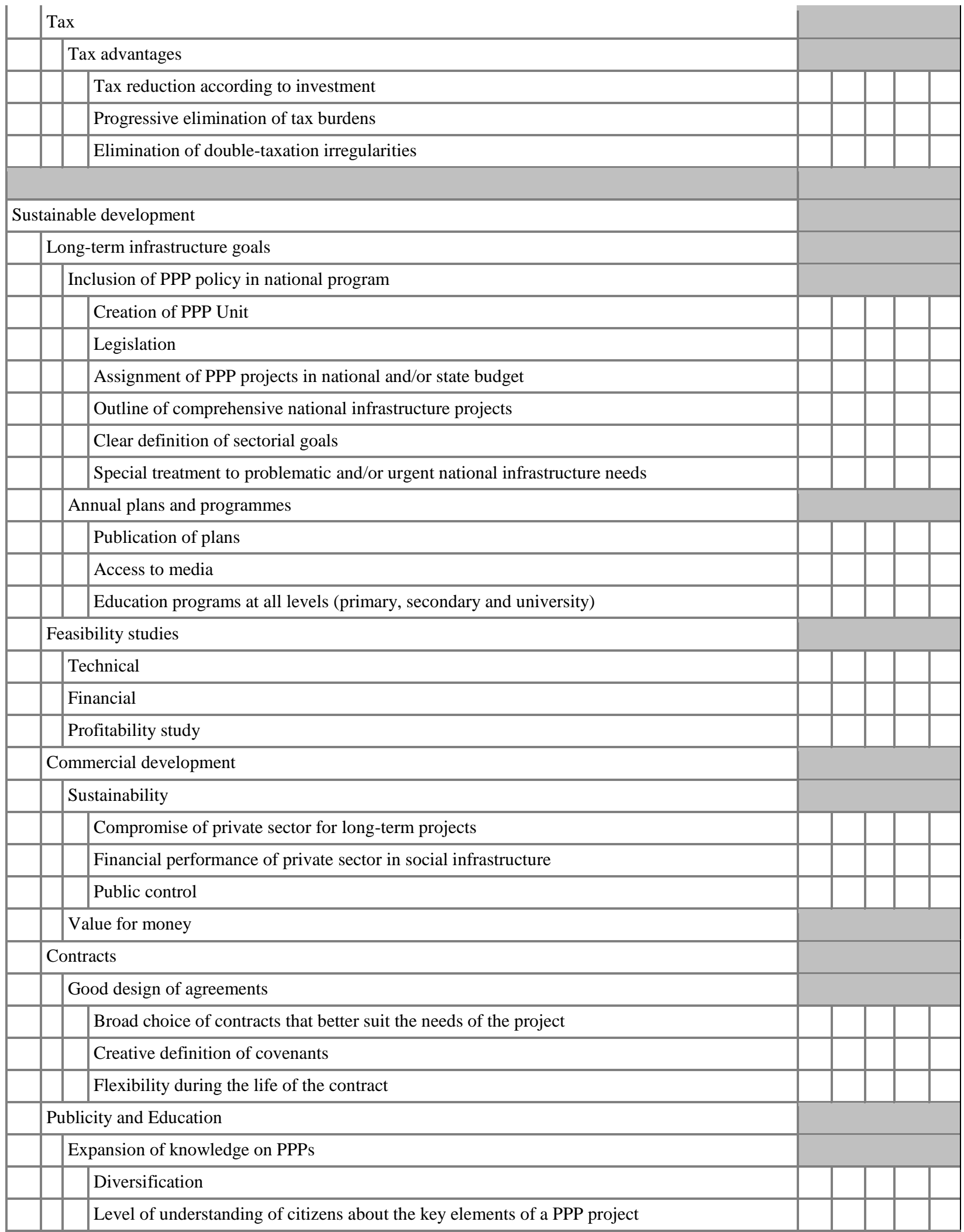




\begin{tabular}{|l|l|l|l|l|l|} 
& Access to media & & & \\
\hline & Polls among users and consumers on performance of the private company & & \\
\hline & Polls to measure public's satisfaction with the service & & \\
\hline & Safety and Security & & \\
\hline & Specialized Safety and Security agency & & & \\
\hline & Performance & & \\
\hline & Instauration of preventive measures & & & \\
\hline & Level of spread of information related to security measures & & & \\
\hline & Periodic exams in the project & & & \\
\hline & Regulation of insurance market & & & \\
\hline & Existence of covenants in agreements & & & \\
\hline
\end{tabular}

Source: Governance in Public Private Partnerships for Infrastructure Development (Draft), Economic Commission for Europe, Committee for Trade, Industry and Enterprise Development, Working Party on International Legal and Commercial Practice (WP.5), October 2005.

\section{Appendix 2 PPP projects in Spain}

\begin{tabular}{|c|c|c|c|c|c|c|c|c|}
\hline $\begin{array}{l}\text { Nombre del } \\
\text { proyecto }\end{array}$ & Sector & CCAA & Dependencia & $\begin{array}{l}\text { Valor } \\
\text { en } \\
€ M\end{array}$ & Fecha & Concesionario & $\begin{array}{l}\text { Estado del } \\
\text { proyecto }\end{array}$ & Notas \\
\hline $\begin{array}{l}\text { Alicante - } \\
\text { Cartagena }\end{array}$ & Carreteras & $\begin{array}{l}\text { Valencia / } \\
\text { Murcia }\end{array}$ & Estado & & 1998 (a) & Ausur & En servicio & $\begin{array}{l}77 \mathrm{~km}, \text { Peaje } \\
\text { (BOT) }\end{array}$ \\
\hline $\begin{array}{l}\text { Tarragona - } \\
\text { Valencia A-7 }\end{array}$ & Carreteras & $\begin{array}{l}\text { Valencia / } \\
\text { Cataluña }\end{array}$ & Estado & & $\begin{array}{l}\text { Anterior a } 1975 \\
\text { (c) }\end{array}$ & Aumar & En Servicio & $\begin{array}{l}225 \mathrm{~km} \text {, Peaje } \\
\text { (BOT) } \\
\text { Valor de }\end{array}$ \\
\hline $\begin{array}{l}\text { Valencia-Losa del } \\
\text { Obispo, CV-35 }\end{array}$ & Carreteras & Valencia & CCAA & 450 & 2005 (a) & $\begin{array}{l}\text { UTE Sacyr- } \\
\text { Nagares-Secopsa }\end{array}$ & $\begin{array}{l}\text { Pendiente el } \\
\text { contrato }\end{array}$ & $\begin{array}{l}\text { construcción - } \\
450 \mathrm{M}, \text { Peaje } \\
\text { en Sombra }\end{array}$ \\
\hline $\begin{array}{l}\text { Variante de } \\
\text { Alicante }\end{array}$ & Carreteras & Valencia & Estado & 445 & 2004 (a) & Ciralsa & $\begin{array}{l}\text { Pendiente el } \\
\text { contrato }\end{array}$ & $\begin{array}{l}\text { Valor de } \\
\text { construcción - } \\
445 \mathrm{M} €\end{array}$ \\
\hline $\begin{array}{l}\text { Hospital Valencia } \\
\text { - Alcira }\end{array}$ & Sanidad & Valencia & CCAA & 123 & $\begin{array}{l}1999 \text { (en } \\
\text { servicio) }\end{array}$ & $\begin{array}{l}\text { Ribera Salud, } \\
\text { UTE - Aldesas }\end{array}$ & En Servicio & $\begin{array}{l}\text { Valor de } \\
\text { Construcción } \\
123 \mathrm{M} €\end{array}$ \\
\hline Hospital Denia & Sanidad & Valencia & CCAA & 97 & 2005 & UTE - DKV & $\begin{array}{l}\text { En } \\
\text { Construcción }\end{array}$ & $\begin{array}{l}\text { Valor de } \\
\text { Construcción } \\
97 \mathrm{M€}\end{array}$ \\
\hline Hospital Torrevieja & Sanidad & Valencia & CCAA & 70 & 2004 & $\begin{array}{l}\text { UTE - Necso y } \\
\text { Enrique Ortiz e } \\
\text { Hijos }\end{array}$ & $\begin{array}{l}\text { En } \\
\text { Construcción }\end{array}$ & $\begin{array}{l}\text { Valor de } \\
\text { Construcción } \\
70 \mathrm{M} €\end{array}$ \\
\hline $\begin{array}{l}\text { Hospital de } \\
\text { Manises-Quart }\end{array}$ & Sanidad & Valencia & CCAA & & 2005 (1) & Sin determinar & $\begin{array}{l}\text { Pendiente el } \\
\text { contrato }\end{array}$ & \\
\hline Valencia - Alicante & Carreteras & Valencia & Estado & & $\begin{array}{l}\text { Anterior a } 1975 \\
\text { (c) }\end{array}$ & Aumar & En servicio & $\begin{array}{l}149 \mathrm{~km} \text {, Peaje } \\
\text { (BOT) }\end{array}$ \\
\hline $\begin{array}{l}\text { Hospital Son } \\
\text { Dureta }\end{array}$ & Sanidad & $\begin{array}{l}\text { Palma de } \\
\text { Mallorca }\end{array}$ & CCAA & 778 & 2005 (1) & Sin determinar & $\begin{array}{l}\text { Pendiente el } \\
\text { contrato }\end{array}$ & $\begin{array}{l}778 \mathrm{M} € \\
\text { (licitación) }\end{array}$ \\
\hline
\end{tabular}




\begin{tabular}{|c|c|c|c|c|c|c|c|c|}
\hline Palma - Manacor & Carreteras & $\begin{array}{l}\text { Palma de } \\
\text { Mallorca }\end{array}$ & CCAA & 116 & abr-04 & $\begin{array}{l}\text { Sacyr } \\
\text { Vallehermoso y } \\
\text { las sociedades } \\
\text { mallorquinas } \\
\text { Melchor } \\
\text { Mascaró, } \\
\text { Aglomsa, Matías } \\
\text { Arrom Biblioni, } \\
\text { Electro } \\
\text { Hidráulica y } \\
\text { Obras y } \\
\text { Pavimentos Man }\end{array}$ & $\begin{array}{l}\text { En } \\
\text { construcion }\end{array}$ & $\begin{array}{l}116 \text { inversion } \\
\text { prevista - Peaje } \\
\text { en Sombra }\end{array}$ \\
\hline Túnel de Soller & Carreteras & $\begin{array}{l}\text { Palma de } \\
\text { Mallorca }\end{array}$ & Estado & & 1990 & Tunel de soller & En servicio & $\begin{array}{l}3 \mathrm{~km}, \text { Peaje } \\
\text { (BOT) }\end{array}$ \\
\hline $\begin{array}{l}\text { Autopista Eibar - } \\
\text { Vitoria }\end{array}$ & Carreteras & $\begin{array}{l}\text { País Vasco / } \\
\text { Navarra }\end{array}$ & CCAA & 721 & $\begin{array}{l}\text { Varios tramos - } \\
\text { EIB funding } \\
\text { close Abril } 2005\end{array}$ & $\begin{array}{l}\text { BIDEGI, SA, } \\
\text { Vias de Alava, } \\
\text { SA }\end{array}$ & $\begin{array}{l}\text { En } \\
\text { Construccion }\end{array}$ & $\begin{array}{l}\text { Valor de } \\
\text { construcción - } \\
721 \mathrm{M} €\end{array}$ \\
\hline Bilbao -Zaragoza & Carreteras & $\begin{array}{l}\text { País Vasco / } \\
\text { Aragón }\end{array}$ & Estado & & $\begin{array}{l}\text { Anterior a } 1975 \\
\text { (c) }\end{array}$ & Avasa & En servicio & $\begin{array}{l}294 \mathrm{~km}, \text { Peaje } \\
\text { (BOT) }\end{array}$ \\
\hline Bilbao - Behobia & Carreteras & País Vasco & Estado & & $\begin{array}{l}\text { Anterior a } 1975 \\
\text { (c) }\end{array}$ & $\begin{array}{l}\text { Concesión } \\
\text { terminó en } 2003\end{array}$ & En servicio & $\begin{array}{l}115 \mathrm{~km} \text {, Peaje } \\
\text { (BOT), ahora } \\
\text { tiene contratos } \\
\text { de servicio bajo } \\
\text { el gobierno } \\
\text { local }\end{array}$ \\
\hline Tudela - Irurzun & Carreteras & País Vasco & Estado & & $\begin{array}{l}\text { Anterior a } 1975 \\
\text { (c) }\end{array}$ & Audenasa & En servicio & $\begin{array}{l}113 \mathrm{~km}, \text { Peaje } \\
(\mathrm{BOT})\end{array}$ \\
\hline Túnel de Artxanda & Carreteras & País Vasco & Estado & & 1998 & Artxanda Tuneles & sEn servicio & $\begin{array}{l}5 \mathrm{~km}, \text { Peaje } \\
(\mathrm{BOT})\end{array}$ \\
\hline $\begin{array}{l}\text { Pamplona-Estella- } \\
\text { Logroño Autovia } \\
\text { de Caminos }\end{array}$ & Carreteras & $\begin{array}{l}\text { Navarra / La } \\
\text { Rioja }\end{array}$ & CCAA & 324 & 2000/2001 (a) & $\begin{array}{l}\text { Autovía del } \\
\text { Camino, S.A. }\end{array}$ & $\begin{array}{l}\text { En } \\
\text { construcción } \\
\text { con varios } \\
\text { tramos } \\
\text { abiertos }\end{array}$ & $\begin{array}{l}\text { Valor de } \\
\text { construcción - } \\
324 \text { M€, Peaje } \\
\text { en Sombra }\end{array}$ \\
\hline $\begin{array}{l}\text { Medinaceli-Soria- } \\
\text { Tudela }\end{array}$ & Carreteras & $\begin{array}{l}\text { Navarra / } \\
\text { Castilla y } \\
\text { León }\end{array}$ & Estado & 631 & & Sin determinar & $\begin{array}{l}\text { Pendiente el } \\
\text { contrato }\end{array}$ & $\begin{array}{l}\text { Valor de } \\
\text { construcción - } \\
631 \mathrm{M} €\end{array}$ \\
\hline $\begin{array}{l}\text { Zona regable del } \\
\text { Canal de Navarra }\end{array}$ & Agua & Navarra & CCAA & 408 & & Sin determinar & $\begin{array}{l}\text { Pendiente } \\
\text { aprobación }\end{array}$ & $\begin{array}{l}\text { Inversion total } \\
600 \mathrm{M} €\end{array}$ \\
\hline Cartagena - Vera & Carreteras & $\begin{array}{l}\text { Murcia / } \\
\text { Andalucía }\end{array}$ & Estado & 526 & & Sin determinar & $\begin{array}{l}\text { Pendiente el } \\
\text { contrato }\end{array}$ & $\begin{array}{l}\text { Valor de } \\
\text { construcción - } \\
526 \mathrm{M}\end{array}$ \\
\hline Segovia-San Rafael & 1Carreteras & $\begin{array}{l}\text { Madrid / } \\
\text { Castilla y } \\
\text { León }\end{array}$ & Estado & 102 & 2001 & $\begin{array}{l}\text { Castellana de } \\
\text { Autopistas/Iberpi } \\
\text { stas }\end{array}$ & En servicio & $\begin{array}{l}\text { Valor de } \\
\text { construcción - } \\
102 \text { M€, Peaje }\end{array}$ \\
\hline $\begin{array}{l}\text { Madrid - Ocaña, R- } \\
4\end{array}$ & - Carreteras & $\begin{array}{l}\text { Madrid / } \\
\text { Castilla La } \\
\text { Mancha }\end{array}$ & Estado & 598 & $2000(\mathrm{a})$ & $\begin{array}{l}\text { Autopista } \\
\text { Madrid-Sur }\end{array}$ & En servicio & $\begin{array}{l}\text { Valor de } \\
\text { construcción - } \\
598 \text { M€, Peaje }\end{array}$ \\
\hline $\begin{array}{l}\text { Madrid - } \\
\text { Guadalajara R-2 }\end{array}$ & Carreteras & $\begin{array}{l}\text { Madrid / } \\
\text { Castilla La } \\
\text { Mancha }\end{array}$ & Estado & 409 & 2000 (a) & Henarsa & En servicio & $\begin{array}{l}\text { Valor de } \\
\text { construcción - } \\
409 \text { M€, Peaje }\end{array}$ \\
\hline Madrid - Toledo & Carreteras & $\begin{array}{l}\text { Madrid / } \\
\text { Castilla La } \\
\text { Mancha }\end{array}$ & Estado & 400 & & Sin determinar & $\begin{array}{l}\text { Pendiente el } \\
\text { contrato }\end{array}$ & $\begin{array}{l}\text { Valor de } \\
\text { construcción - } \\
400 \text { M€, Peaje }\end{array}$ \\
\hline
\end{tabular}




\begin{tabular}{|c|c|c|c|c|c|c|c|c|}
\hline M-30 & Carreteras & Madrid & CCAA & 2458 & $\begin{array}{l}2003(\mathrm{a}) ; \text { varios } \\
\text { tramos }\end{array}$ & $\begin{array}{l}\text { Varios Tramos - } \\
\text { OHL, } \\
\text { CORSAN/CORV } \\
\text { IAM, UTE } \\
\text { SANDO/PLODO } \\
\text {, ALDESA, UTE } \\
\text { Ortiz/Ogensa, } \\
\text { SACYR, UTE } \\
\text { NEXO/Ferrovial, } \\
\text { UTE } \\
\text { Dragados/FCC, }\end{array}$ & En & $\begin{array}{l}\text { Valor de } \\
\text { construcción - } \\
2458 \mathrm{M€}\end{array}$ \\
\hline $\begin{array}{l}\text { Madrid-Arganda y } \\
\text { Madrid - } \\
\text { Navalcarnero, R-3 } \\
\text { y R-5 }\end{array}$ & Carreteras & Madrid & Estado & 841 & 1999 & $\begin{array}{l}\text { Amsa - Accesos } \\
\text { madrid }\end{array}$ & En servicio & $\begin{array}{l}\text { Valor de } \\
\text { construcción - } \\
841 \text { M€, Peaje }\end{array}$ \\
\hline $\begin{array}{l}\text { M- } 45 \text { Various } \\
\text { Tramos }\end{array}$ & Carreteras & Madrid & CCAA & 487 & $\begin{array}{l}\text { 1998; varios } \\
\text { tramos }\end{array}$ & $\begin{array}{l}\text { Concesiones de } \\
\text { Madrid, } \\
\text { Autopista } \\
\text { Trados-45, } \\
\text { Autopista } \\
\text { Trados-45 }\end{array}$ & En servicio & $\begin{array}{l}\text { Valor de } \\
\text { construcción - } \\
487 \text { M€, Peaje } \\
\text { en sombra }\end{array}$ \\
\hline $\begin{array}{l}\text { Autopista Eje } \\
\text { Barajas }\end{array}$ & Carreteras & Madrid & Estado & 328 & 2002 (a) & Eje Aeropuerto & $\begin{array}{l}\text { En } \\
\text { construcción }\end{array}$ & $\begin{array}{l}\text { Valor de } \\
\text { construcción - } \\
328 \text { M€, Peaje }\end{array}$ \\
\hline $\begin{array}{l}\text { Majahonda } \\
\text { Hospital }\end{array}$ & Sanidad & Madrid & CCAA & 256 & & Bovis Lend Lease & $\mathrm{e}_{\text {construcción }}^{\text {En }}$ & $\begin{array}{l}\text { Valor de } \\
\text { construcción } \\
256 \mathrm{M} €\end{array}$ \\
\hline $\begin{array}{l}\text { Ruta de Pantanos } \\
\text { M-503 }\end{array}$ & Carreteras & Madrid & CCAA & 100,7 & 1999 (a) & Acciona & En servicio & $\begin{array}{l}\text { Valor de } \\
\text { construcción - } \\
100,7 \mathrm{M} € \\
\text { Peaje en } \\
\text { Sombra }\end{array}$ \\
\hline $\begin{array}{l}\text { Hospital - } \\
\text { Valdebernado Sur }\end{array}$ & Sanidad & Madrid & CCAA & 98,7 & 2005 & $\begin{array}{l}\text { Begar y Ploder en } \\
\text { consorcio con } \\
\text { Idissa, Vectrinsa, } \\
\text { Fuensanta y } \\
\text { Cantoblanco }\end{array}$ & $\begin{array}{l}\text { Pendiente el } \\
\text { contrato }\end{array}$ & $\begin{array}{l}\text { Valor de } \\
\text { construcción } \\
98.7 \mathrm{M} €\end{array}$ \\
\hline $\begin{array}{l}\text { Hospital - San } \\
\text { Sebastián de los } \\
\text { Reyes }\end{array}$ & Sanidad & Madrid & CCAA & 98,2 & 2005 & $\begin{array}{l}\text { Acciona, S.A y } \\
\text { Crespo y Blasco, } \\
\text { S.A }\end{array}$ & $\begin{array}{l}\text { Pendiente el } \\
\text { contrato }\end{array}$ & $\begin{array}{l}\text { Valor de } \\
\text { construcción } \\
\text { 98.2 M€ }\end{array}$ \\
\hline Tranvía de Parla & Transporte & Madrid & CCAA & 93,5 & 2005 (a) & $\begin{array}{l}\text { UTE que han } \\
\text { FCC y Acciona }\end{array}$ & $\begin{array}{l}\text { Pendiente el } \\
\text { contrato }\end{array}$ & $\begin{array}{l}\text { Valor de } \\
\text { construcción - } \\
93,5 \text { M€ } \\
\text { Valor de }\end{array}$ \\
\hline $\begin{array}{l}\text { M-407, en } \\
\text { Fuenlabrada }\end{array}$ & Carreteras & Madrid & CCAA & 70,3 & 2005 (a) & $\begin{array}{l}\text { FCC } \\
\text { Construcción }\end{array}$ & $\begin{array}{l}\text { Pendiente el } \\
\text { contrato }\end{array}$ & $\begin{array}{l}\text { construcción - } \\
\text { 70,3 M€, Peaje } \\
\text { en Sombra }\end{array}$ \\
\hline $\begin{array}{l}\text { Hospital - Jarma - } \\
\text { Coslada }\end{array}$ & Sanidad & Madrid & CCAA & 66,7 & 2005 & $\begin{array}{l}\text { Sacyr, S.A, Testa } \\
\text { Inmuebles en } \\
\text { Renta, S.A. y } \\
\text { Valoriza } \\
\text { Facilities, S.A.U }\end{array}$ & $\begin{array}{l}\text { Pendiente el } \\
\text { contrato }\end{array}$ & $\begin{array}{l}\text { Valor de } \\
\text { construcción } \\
66.7 \mathrm{M} €\end{array}$ \\
\hline $\begin{array}{l}\text { Hospital - Los } \\
\text { Conejeras }\end{array}$ & Sanidad & Madrid & CCAA & 64,4 & 2005 & $\begin{array}{l}\text { Sacyr, S.A., Testa } \\
\text { Inmuebles en } \\
\text { Renta, S.A. y } \\
\text { Valoriza } \\
\text { Facilities, S.A.U }\end{array}$ & $\begin{array}{l}\text { Pendiente el } \\
\text { contrato }\end{array}$ & $\begin{array}{l}\text { Valor de } \\
\text { construcción } \\
64.4 \mathrm{M} €\end{array}$ \\
\hline
\end{tabular}




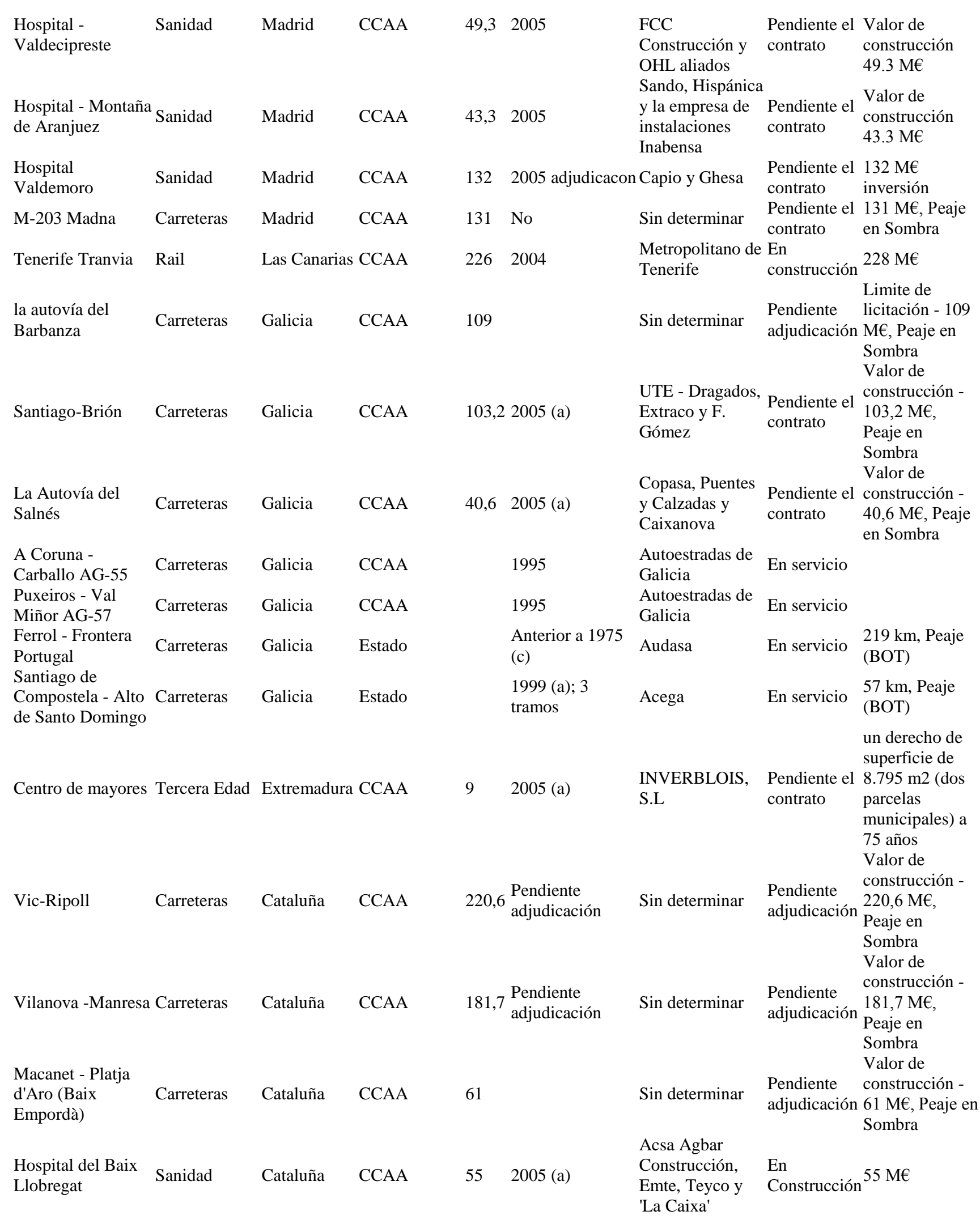




\begin{tabular}{|c|c|c|c|c|c|c|c|c|}
\hline Reus-Alcover, & Carreteras & Cataluña & CCAA & 51,4 & 2005 (a) & $\begin{array}{l}\text { Dragados } \\
\text { Concesiones de } \\
\text { Infraestructuras- } \\
\text { Benito Arnó e } \\
\text { Hijos SA }\end{array}$ & $\begin{array}{l}\text { Pendiente el } \\
\text { contrato }\end{array}$ & $\begin{array}{l}\text { Valor de } \\
\text { construcción - } \\
51,4 \text { M€, Peaje } \\
\text { en Sombra }\end{array}$ \\
\hline $\begin{array}{l}\text { Barcelona - La } \\
\text { Jonquera A-7 }\end{array}$ & Carreteras & Cataluña & Estado & & $\begin{array}{l}\text { Anterior a } 1975 \\
\text { (c) }\end{array}$ & Acesa & En servicio & $\begin{array}{l}150 \mathrm{~km}, \text { Peaje } \\
(\mathrm{BOT})\end{array}$ \\
\hline $\begin{array}{l}\text { Barcelona } \\
\text { (Granollers) - } \\
\text { Montmelo C-33 }\end{array}$ & Carreteras & Cataluña & Estado & & $\begin{array}{l}\text { Anterior a } 1975 \\
\text { (c) }\end{array}$ & Acesa & En servicio & $\begin{array}{l}14,1 \mathrm{~km}, \text { Peaje } \\
(\mathrm{BOT})\end{array}$ \\
\hline $\begin{array}{l}\text { Barcelona - } \\
\text { Tarragona A-7 }\end{array}$ & Carreteras & Cataluña & Estado & & $\begin{array}{l}\text { Anterior a } 1975 \\
\text { (c) }\end{array}$ & Acesa & En servicio & $\begin{array}{l}100 \mathrm{kn}, \text { Peaje } \\
(\mathrm{BOT})\end{array}$ \\
\hline $\begin{array}{l}\text { Castelldefels - El } \\
\text { Vendrell }\end{array}$ & Carreteras & Cataluña & Estado & & 1992 / 1998 (i) & Aucat 2 tramos & En servicio & $\begin{array}{l}58 \mathrm{~km} \text {, Peaje } \\
(\mathrm{BOT})\end{array}$ \\
\hline Montgat - Palafolls & Carreteras & Cataluña & Estado & & $\begin{array}{l}\text { Anterior a } 1975 \\
\text { (c) }\end{array}$ & Acesa & En servicio & $\begin{array}{l}49 \mathrm{~km} \text {, Peaje } \\
\text { (BOT) }\end{array}$ \\
\hline $\begin{array}{l}\text { Montmelo - El } \\
\text { Papiol A-7 }\end{array}$ & Carreteras & Cataluña & Estado & & $\begin{array}{l}\text { Anterior a } 1975 \\
\text { (c) }\end{array}$ & Acesa & En servicio & $\begin{array}{l}26,8 \mathrm{~km} \text {, Peaje } \\
\text { (BOT) }\end{array}$ \\
\hline $\begin{array}{l}\text { Terrassa - } \\
\text { Manresa/Sant } \\
\text { Cugat }\end{array}$ & Carreteras & Cataluña & Estado & & $\begin{array}{l}1989 \text { (en } \\
\text { servicio) }\end{array}$ & Autema & En servicio & $\begin{array}{l}43 \mathrm{~km} \text {, Peaje } \\
\text { (BOT) }\end{array}$ \\
\hline Tunel del Cadi & Carreteras & Cataluña & Estado & & $\begin{array}{l}\text { Anterior a } 1975 \\
\text { (c) }\end{array}$ & Túnel de cadi & En servicio & $\begin{array}{l}30 \mathrm{~km} \text {, Peaje } \\
\text { (BOT) }\end{array}$ \\
\hline $\begin{array}{l}\text { Túneles de } \\
\text { Vallvidrera }\end{array}$ & Carreteras & Cataluña & Estado & & $\begin{array}{l}\text { Anterior a } 1975 \\
\text { (c) }\end{array}$ & Tabasa & En servicio & $\begin{array}{l}17 \mathrm{~km} \text {, Peaje } \\
\text { (BOT) }\end{array}$ \\
\hline $\begin{array}{l}\text { Zaragoza - } \\
\text { Mediterráneo A-2 }\end{array}$ & Carreteras & Cataluña & Estado & & $\begin{array}{l}\text { Anterior a } 1975 \\
\text { (c) }\end{array}$ & Acesa & En servicio & $\begin{array}{l}215 \mathrm{~km} \text {, Peaje } \\
\text { (BOT) }\end{array}$ \\
\hline Eje Llobregat & Carreteras & Cataluña & CCAA & 240 & $\begin{array}{l}\text { Adjudicación } \\
2005\end{array}$ & $\begin{array}{l}\mathrm{FCC} / \mathrm{COPISCA} / \\
\text { CORNSA/ } \\
\text { COPISA }\end{array}$ & & $\begin{array}{l}240 \mathrm{M} € \text {, Peaje } \\
\text { en Sombra }\end{array}$ \\
\hline Cuitat de la Justicia & Las Cortes & Cataluña & CCAA & 263 & 2005 & Sin determinar & $\begin{array}{l}\text { Pendiente el } \\
\text { contrato }\end{array}$ & $263 \mathrm{M} €$ \\
\hline $\begin{array}{l}\text { Tranvía Barcelona } \\
\text { Baix Llobregat }\end{array}$ & Rail & Cataluña & CCAA & 217 & 2000 & $\begin{array}{l}\text { Tramvia } \\
\text { Metropolità }\end{array}$ & En servicio & $217 \mathrm{M} €$ \\
\hline $\begin{array}{l}\text { Tranvía Barcelona } \\
\text { Besós }\end{array}$ & Rail & Cataluña & CCAA & 212 & $\begin{array}{l}2002 \\
\text { adjudicación }\end{array}$ & FCC-Connex & En Servicio & $212 \mathrm{M} €$ \\
\hline Burgos - Armiñón & Carreteras & $\begin{array}{l}\text { Castilla y } \\
\text { León / País } \\
\text { Vasco }\end{array}$ & Estado & & $\begin{array}{l}\text { Anterior a } 1975 \\
\text { (c) }\end{array}$ & Europistas & En servicio & $\begin{array}{l}84 \text { km, Peaje } \\
\text { (BOT) }\end{array}$ \\
\hline $\begin{array}{l}\text { Conexión A1/A68 } \\
\text { Haro-Pancorbo }\end{array}$ & Carreteras & $\begin{array}{l}\text { Castilla y } \\
\text { León / La } \\
\text { Rioja }\end{array}$ & Estado & 99 & & Sin determinar & $\begin{array}{l}\text { Pendiente el } \\
\text { contrato }\end{array}$ & $\begin{array}{l}\text { Valor de } \\
\text { construcción - } \\
99 \mathrm{M} €\end{array}$ \\
\hline $\begin{array}{l}\text { Leon - } \\
\text { Campomanes }\end{array}$ & Carreteras & $\begin{array}{l}\text { Castilla y } \\
\text { León / } \\
\text { Asturias }\end{array}$ & Estado & & $\begin{array}{l}\text { Anterior a } 1975 \\
\text { (c) }\end{array}$ & Aucalsa & En servicio & $\begin{array}{l}78 \mathrm{~km} \text {, Peaje } \\
\text { (BOT) }\end{array}$ \\
\hline Valladolid-Segovia & Carreteras & $\begin{array}{l}\text { Castilla y } \\
\text { León }\end{array}$ & CCAA & 196 & 2006 (a) & $\begin{array}{l}\text { Dos Tramos - } \\
\text { Dragados, } \\
\text { Cyopsa y Caja } \\
\text { Duero - Sacyr } \\
\text { Vallehermoso y } \\
\text { Construcciones } \\
\text { Lerma }\end{array}$ & $\begin{array}{l}\text { Pendiente el } \\
\text { contrato }\end{array}$ & $\begin{array}{l}\text { Valor de } \\
\text { construcción - } \\
196 \text { M€, Peaje } \\
\text { en Sombra }\end{array}$ \\
\hline Hospital de Burgos & Sanidad & $\begin{array}{l}\text { Castilla y } \\
\text { León }\end{array}$ & CCAA & 163,8 & & Sin determinar & $\begin{array}{l}\text { Pendiente el } \\
\text { contrato }\end{array}$ & $\begin{array}{l}\text { Valor de } \\
\text { Construcción } \\
\text { 163,8 M€ }\end{array}$ \\
\hline $\begin{array}{l}\text { Autopista Léon - } \\
\text { Astorga }\end{array}$ & Carreteras & $\begin{array}{l}\text { Castilla y } \\
\text { León }\end{array}$ & Estado & 110 & 1999 & Avelesa & En servicio & $\begin{array}{l}\text { Valor de } \\
\text { construcción - } \\
110 \mathrm{M} \text {, Peaje }\end{array}$ \\
\hline
\end{tabular}




\begin{tabular}{|c|c|c|c|c|c|c|c|c|}
\hline Adanero -Villalba & Carreteras & $\begin{array}{l}\text { Castilla y } \\
\text { León }\end{array}$ & Estado & & $\begin{array}{l}\text { Anterior a } 1975 \\
\text { (c) }\end{array}$ & Iberpistas & En servicio & $\begin{array}{l}28 \mathrm{~km} \text {, Peaje } \\
(\mathrm{BOT})\end{array}$ \\
\hline $\begin{array}{l}\text { Toledo-Ciudad } \\
\text { Real }\end{array}$ & Carreteras & $\begin{array}{l}\text { Castilla La } \\
\text { Mancha }\end{array}$ & Estado & 1382 & & Sin determinar & $\begin{array}{l}\text { Pendiente el } \\
\text { contrato }\end{array}$ & $\begin{array}{l}\text { Valor de } \\
\text { construcción - } \\
1382 \text { M€ }\end{array}$ \\
\hline Ocaña - La Roda & Carreteras & $\begin{array}{l}\text { Castilla La } \\
\text { Mancha }\end{array}$ & Estado & 525 & 2004 (a) & $\begin{array}{l}\text { Autopistas } \\
\text { Madrid-levante }\end{array}$ & $\begin{array}{l}\text { En } \\
\text { Construcción }\end{array}$ & $\begin{array}{l}\text { Valor de } \\
\text { construcción - } \\
525 \text { M€, Peaje }\end{array}$ \\
\hline $\begin{array}{l}\text { Mantenimiento de } \\
\text { carreteras Toledo } \\
\text { Zona } 1\end{array}$ & Carreteras & $\begin{array}{l}\text { Castilla La } \\
\text { Mancha }\end{array}$ & CCAA & 36,2 & $2006(1)$ & Sin determinar & $\begin{array}{l}\text { Pendiente el } \\
\text { contrato }\end{array}$ & mantenimiento \\
\hline $\begin{array}{l}\text { Mantenimiento de } \\
\text { carreteras Toledo } \\
\text { Zona } 2\end{array}$ & Carreteras & $\begin{array}{l}\text { Castilla La } \\
\text { Mancha }\end{array}$ & CCAA & 27,1 & $2007(1)$ & Sin determinar & $\begin{array}{l}\text { Pendiente el } \\
\text { contrato }\end{array}$ & mantenimiento \\
\hline $\begin{array}{l}\text { Mantenimiento de } \\
\text { carreteras Toledo } \\
\text { Zona } 3\end{array}$ & Carreteras & $\begin{array}{l}\text { Castilla La } \\
\text { Mancha }\end{array}$ & CCAA & 34,1 & $2008(1)$ & Sin determinar & $\begin{array}{l}\text { Pendiente el } \\
\text { contrato }\end{array}$ & mantenimiento \\
\hline $\begin{array}{l}\text { Autovía los } \\
\text { Viñedos Tramo } 1 \\
\text { Suegra Tomelloso }\end{array}$ & Carreteras & $\begin{array}{l}\text { Castilla - La } \\
\text { Mancha }\end{array}$ & CCAA & 170 & 2003 (a) & $\begin{array}{l}\text { Construcciones } \\
\text { Sarrión, } \\
\text { Construcciones } \\
\text { Gismero y Caja } \\
\text { Castilla-La } \\
\text { Mancha }\end{array}$ & $\begin{array}{l}\text { En } \\
\text { construcción }\end{array}$ & $\begin{array}{l}\text { Valor de } \\
\text { construcción - } \\
170 \mathrm{M} € \text {, Valor } \\
\text { total } 295 \text { Peaje } \\
\text { en sombra }\end{array}$ \\
\hline $\begin{array}{l}\text { Autovía los } \\
\text { Viñedos Tramo } 2 \\
\text { Toledo (Mora) } \\
\text { Suegra }\end{array}$ & Carreteras & $\begin{array}{l}\text { Castilla - La } \\
\text { Mancha }\end{array}$ & CCAA & 136 & 2003 (a) & $\begin{array}{l}\text { Dragados y } \\
\text { Cyopsa }\end{array}$ & & $\begin{array}{l}\text { Valor } \\
\text { construcción } \\
\text { 136, Valor total } \\
332 \text { M€, Peaje } \\
\text { en sombra }\end{array}$ \\
\hline Centro de residuos & Residuos & Cantabria & CCAA & 39 & 2005 & Urbaser & $\begin{array}{l}\text { Pendiente el } \\
\text { contrato }\end{array}$ & $39 \mathrm{M} €$ \\
\hline Ibiza Sun Antonio & Carreteras & Balearas & CCAA & 70 & No & Sin determinar & $\begin{array}{l}\text { Pendiente el } \\
\text { contrato }\end{array}$ & $\begin{array}{l}70 \mathrm{M} € \text {, Peaje en } \\
\text { Sombra } \\
\text { Limite de }\end{array}$ \\
\hline Oviedo - Porceyo & Carreteras & Asturias & CCAA & 129 & & Sin determinar & $\begin{array}{l}\text { Pendiente } \\
\text { adjudicación }\end{array}$ & $\begin{array}{l}\text { licitación - } 129 \\
\text { M€, Peaje en } \\
\text { Sombra }\end{array}$ \\
\hline Oviedo y Gijón & Carreteras & Asturias & CCAA & 121 & 2005 (a) & $\begin{array}{l}\text { Sacyr } \\
\text { Vallehermoso }\end{array}$ & $\begin{array}{l}\text { Pendiente el } \\
\text { contrato }\end{array}$ & $\begin{array}{l}\text { Valor de } \\
\text { construcción - } \\
121 \text { M€, Peaje } \\
\text { en Sombra }\end{array}$ \\
\hline Autopista de Ebro & Carreteras & Aragón & CCAA & 118 & Fin 2005 (a) & Sin determinar & $\begin{array}{l}\text { Pendiente el } \\
\text { adjudicación }\end{array}$ & $\begin{array}{l}\text { Valor de } \\
\text { construcción - } \\
80-118 \mathrm{M} € \text {, } \\
\text { Peaje en } \\
\text { Sombra }\end{array}$ \\
\hline $\begin{array}{l}\text { El Burgo de Ebro y } \\
\text { Villafranca de Ebro }\end{array}$ & Carreteras & Aragon & CCAA & 85 & $\begin{array}{l}\text { Adudicacion } \\
2005 \mathrm{dec}\end{array}$ & $\begin{array}{l}\text { Acciona-Brues y } \\
\text { Fernández CC y } \\
\text { Arascon }\end{array}$ & $\begin{array}{l}\text { Pendiente el } \\
\text { contrato }\end{array}$ & $\begin{array}{l}85 \mathrm{M} € \text {, Peaje } \\
\text { en Sombra }\end{array}$ \\
\hline Alto de las pedrizas & s Carreteras & $\begin{array}{l}\text { Andalucía } \\
\text { (Malaga) }\end{array}$ & Estado & 421 & $2005(1)$ & Sin determinar & $\begin{array}{l}\text { Pendiente el } \\
\text { contrato }\end{array}$ & $\begin{array}{l}\text { limite licitación } \\
\text {-421 M€ }\end{array}$ \\
\hline $\begin{array}{l}\text { Ferrocarril Costa } \\
\text { del Sol }\end{array}$ & Transporte & Andalucía & CCAA & 2337 & & Sin determinar & & $2337 \mathrm{M} €$ \\
\hline Málaga-Estepona & Carreteras & Andalucía & Estado & 481 & 1996 & $\begin{array}{l}\text { autopista del sol } \\
\text { Ausol }\end{array}$ & En servicio & $\begin{array}{l}\text { Valor de } \\
\text { construcción - } \\
481 \text { M€, Peaje }\end{array}$ \\
\hline
\end{tabular}




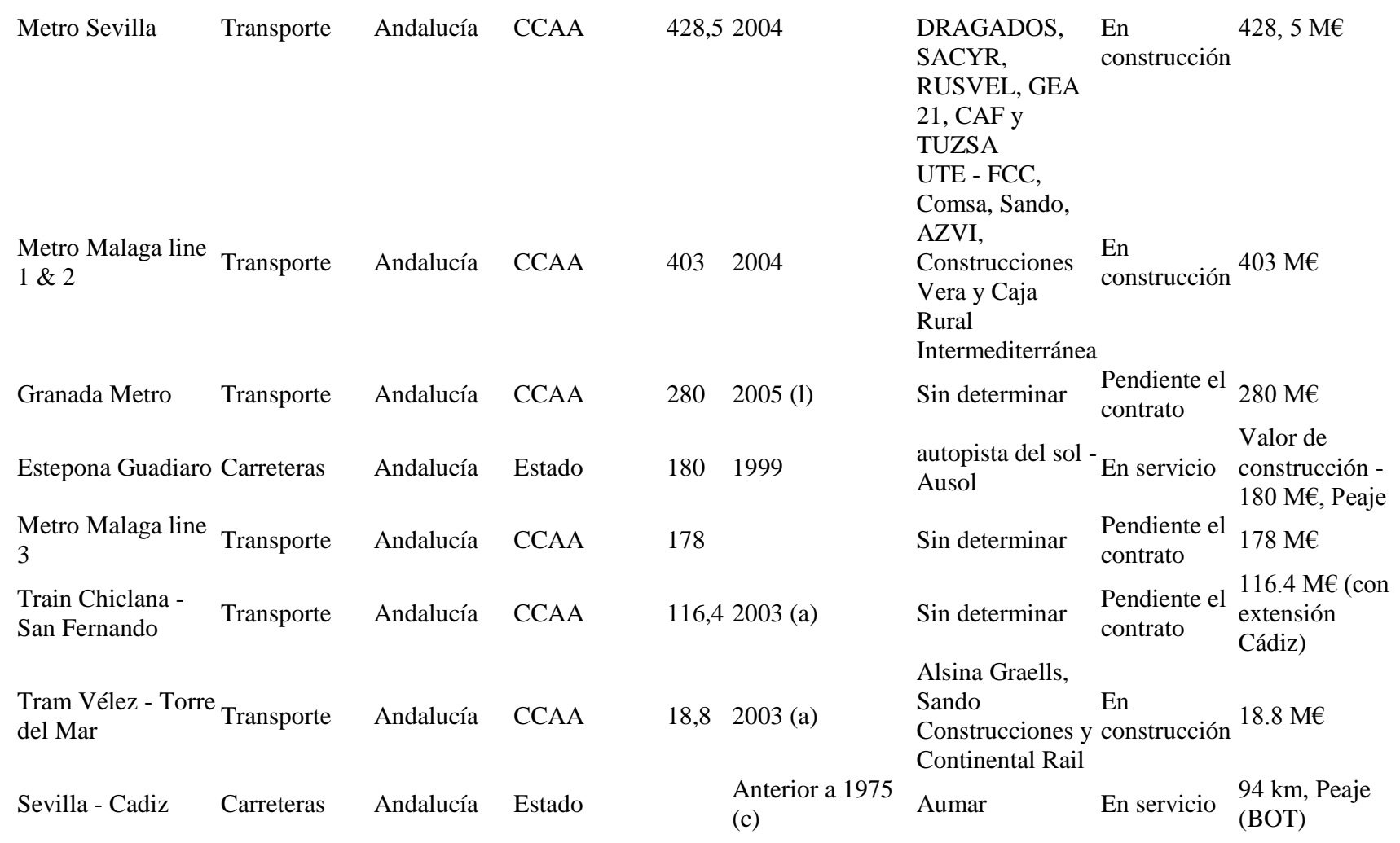

\section{NOTES}


NOTES 